\title{
Ecological Factors and the Distribution of Adult Odonata in Puerto Rico ${ }^{1}$
}

\author{
Ariel Díaz ${ }^{2}$, Delwin J. Rodríguez-Flores ${ }^{2}$, Ana G. Rivera-Vega ${ }^{2}$, \\ Edgardo Cruz-Marcano ${ }^{2}$, Iris M. Velázquez-Oliveras ${ }^{2}$, and \\ Luis A. Villanueva-Cubero ${ }^{3}$
}

\begin{abstract}
Puerto Rico's dragonfly and damselfly (Odonata) fauna, while abundant and diverse, is not well known, with the most recent surveys being over 80 years old. This work reports on sampling conducted on the island between late 2015 and early 2017 . A total of 1,754 specimens in 19 genera and 30 species were collected, representing $61.2 \%$ of the species reported for the island. The number of individuals, number of genera, and number of species were higher on sites with a mean annual precipitation between $1300 \mathrm{~mm}$ and $1900 \mathrm{~mm}$ and a mean maximum annual temperature between $28.51^{\circ} \mathrm{C}$ and $32.50^{\circ} \mathrm{C}$. Similarly, the number of individuals, number of genera, and number of species were higher on the woodland and shrubland cover types than on any of the other cover types. While some inferences can be made from our data, an increased collection effort in less sampled areas is necessary.
\end{abstract}

Key Words: Odonata, adults, precipitation, temperature, cover type, Holdridge life zones, Puerto Rico

Insect species exist within a specific range of climatic variables. Consequently, for any geographic region, the abundance of insects and the distribution of their populations are determined, in part, by abiotic variables, such as precipitation and temperature, as well as other climatic parameters. For example, the abundance and species richness of saturniid moths (Lepidoptera) exhibit a positive relation with both temperature and evapotranspiration in a Mexican semi-deciduous forest, where the highest percentage of species was captured during the hottest month of the year (Lara-Peréz et al. 2017). In Rio Grande do Sul, Brazil, Azevedo and Krüger (2013) found that both temperature and relative humidity are related to species richness of blowflies (Calliphoridae) while species abundance was only correlated with temperature. In New Zealand landscapes, temperature has been found to be a good predictor for the presence of both established and non-established insect pests (Peacock et al. 2006). Similarly, abundance and species richness of dung beetles are strongly correlated with rainfall in semi-arid Brazil, where an increase in abundance occurs at the beginning of the wet season (Liberal et al. 2011).

\footnotetext{
${ }^{1}$ Received on December 11, 2019. Accepted on December 18, 2019. Last revisions received on December 30, 2019.

${ }^{2}$ Department of Biology, University of Puerto Rico at Humacao, Call Box 8690, Humacao, Puerto Rico 00792. Emails: ariel.diaz@upr.edu (AD), delwin.rodriguez@upr.edu (DRF), ana.rivera17@upr.edu (ARV), edgardo.cruz4@upr.edu (ECM), iris.velazquez@upr.edu (IMVO).

${ }^{3}$ HC-05 Box 53274, Aguadilla, Puerto Rico 00603. E-mail: 1villanuevacubero@gmail.com
}

DOI: 10.9784/LEB7(3)Diaz.01

Electronically available on December 31, 2019. Mailed on December 31, 2019. 
It has been suggested that increasing temperatures associated with global climate change will result in changes in species distribution and abundance and in a northward shift of many northern hemisphere animals, including arthropods (Hickling et al. 2005, 2006). Among arthropods, distribution trends in Odonata have received considerable attention in the last two decades. Powney et al. (2015) suggest that increased temperature in Britain and Ireland may favor the generalist species of Odonata (dragon- and damselflies), which may adapt better to warmer conditions. In the United States, the establishment of Tholymis citrina Hagen and Tramea calverti Muttkowski, two tropical species recently found in Florida, may be attributed to the effects of global warming (Paulson 2001). Similarly, Hickling et al. $(2005,2006)$ showed that British Odonata have exhibited a northward annual shift possibly in response to increased temperatures due to global climate change. Oertli (2010) has suggested that in Switzerland species richness will be higher due to new species extending their range because of climate change. In the United States, the warmer and more humid southeastern states have a higher richness of Odonata than the drier or colder states (Hassall 2012). Species occurrence and species richness in the southwestern states of California and Nevada are known to be positively correlated with precipitation (Ball-Damerow et al. 2014), and climate change can be expected to result in changes in species assemblages on those areas.

Like other islands on the West Indies, the odonate fauna of Puerto Rico is not well known (Paulson 2004). Only two major works on the island's odonate fauna have been published, and they both date to the 1930s. Klots (1932) provides the first, and very extensive, treatment of the fauna of Puerto Rico and the Virgin Islands, listing a total of 36 species for Puerto Rico. García-Díaz (1938) publication lists a total of 43 species but includes species known only from the collection of immature specimens. Based on Paulson (2004), the number of species on the island is 49 but a recent checklist Meurgey (2013) lists a total of only 39 species. Gutierrez et al. (2013) work on aquatic insects of Puerto Rico lists five families (Aeshnidae, Coenagrionidae, Lestidae, Libellulidae, and Protoneuridae) present on the island and is the most recent work on this subject. There are considerable discrepancies as to what the number of species of Odonata in Puerto Rico is. This lack of knowledge extends to the distribution and abundance of odonates in Puerto Rico.

This work is part of The Dragonfly Project (https://prlsamp.rcse.upr.edu/index.php/events/47-dragonfly-project), an islandwide survey of the Odonata on the main island of Puerto Rico and on the island of Vieques, located within the Puerto Rican archipelago. We used Geographic Information Systems (GIS) to examine how the distribution and abundance of the island's odonate fauna are shaped by precipitation and maximum and minimum temperatures. GIS was also used to examine the distribution and abundance of Odonata across Holdridge Life Zones and cover types. 


\section{Methods}

Puerto Rico, the smallest of the Greater Antilles, is located between latitudes $17^{\circ} 45^{\prime} \mathrm{N}$ and $18^{\circ} 30^{\prime} \mathrm{N}$ and longitudes $65^{\circ} 45^{\prime} \mathrm{W}$ and $67^{\circ} 15^{\prime} \mathrm{W}$. The main island is approximately $8900 \mathrm{~km} 2$ and has a mean annual temperature of approximately $25^{\circ} \mathrm{C}$, ranging from a mean low of $19.4^{\circ} \mathrm{C}$ to a mean high of $29.7^{\circ} \mathrm{C}(1963$ to 1995 , Daly et al. 2003). Precipitation for the same period averages $1687 \mathrm{~mm} /$ year, with a dry season occurring in the winter (low of $68 \mathrm{~mm}$ in February) and a wet season in the summer (high of $219 \mathrm{~mm}$ in October) (Daly et al. 2003, Taylor and Alfaro2005). Orographic effects due to the central mountain range result in a drier and warmer southern region and a wetter and cooler northern region (Calvesbert 1970, Larsen and Torres 1996).

Eight collection zones were established on the island (Figure 1) using the following grid arrangement (latitude and longitude for northwest and southeast corners): Zone 1, Aguadilla: (18.500, -67.166) and (18.167, -66.867), Zone 2, Arecibo: (18.500, -66.867) and (18.208, -66.500), Zone 3, Bayamón: (18.500, 66.500) and (18.208, -66.117), Zone 4, Río Piedras: (18.458, -66.117) and (18.208, -65.617), Zone 5, Mayagüez: (18.167, -67.166) and (17.867, -66.867), Zone 6, Ponce: $(18.208,-66.867)$ and $(17.867,-66.500)$, Zone 7, Cayey: (18.208, -66.500) and (17.867, -66.117) Zone 8, Humacao: (18.208, -66.117) and (17.867, -65.617). Each collection zone was assigned to one of eight different collection groups (3-4 individuals per group) based on the presence of college campuses within each zone.

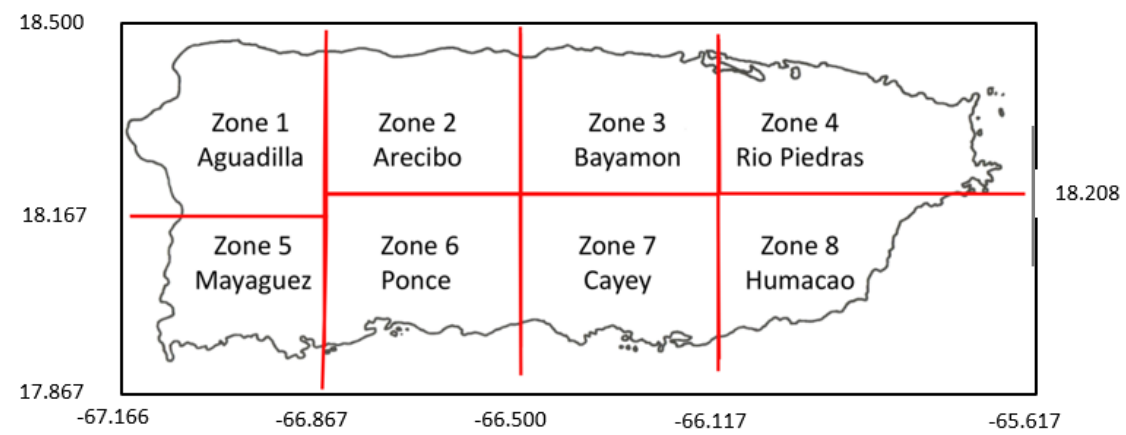

Figure 1. Odonata collection zones in Puerto Rico used in this study. Map produced by The Dragonfly Project. https://prlsamp.rcse.upr.edu/downloads/dragonfly2016/Dragonfly_Mapa_Puerto_Rico_z onas.pdf

We used topographic and road maps to determine collection sites based on their accessibility. Collections were made between December 2015 and February 2017. Adult Odonata were collected using aerial nets and all specimens collected were immediately preserved in $100 \%$ acetone for $24 \mathrm{hr}$. Specimens were then 
placed in cellophane envelopes, labeled, and later identified to the species level using available keys. Specimens and data were gathered in group meetings that took place approximately every six months. The most recent key to the local odonate fauna is found in Klots (1932) work on Puerto Rican Odonata. Additional keys by Westfall and May (2006) and Garrison et al. (2006, 2010) were used for identification. A single project database (DragonflyData) was compiled in MS Excel with data from all eight collection groups. The database includes the date, location name, coordinates, elevation, and species identification. The Odonata collection is deposited in the Museum of Zoology at the University of Puerto Rico, Río Piedras.

To evaluate the effectiveness of the collection effort we created an individualbased species accumulation curve (Gotelli and Colwell 2001, Colwell et al. 2004) following the Michaelis-Menten equation using the PAST 3.0 statistical software (PAST 3.0, Hammer et al. 2001). Spatial analysis was conducted utilizing ArcGIS Software (version 10.5; Environmental Systems Research Institute, Redlands, California). A Geographic Information Systems (GIS) shapefile was constructed by importing DragonflyData file into ArcMap to create a distribution polygon. We obtained ecological data sets for relevant bioclimatic variables from the Caribbean Landscape Conservation Cooperative (CLCC 2017). The following data sets were used: Annual precipitation, Maximum annual temperature, Minimum annual temperature, Holdridge Life Zones, and land cover. Shapefiles for Annual precipitation, Maximum annual temperature, and Minimum annual temperature are based on Daly et al. (2003) and have a $450 \mathrm{~m}$ resolution. Annual precipitation (in $\mathrm{mm}$ ) was divided into seven categories (RaL,700.00 - 1000.00; Ra-LM, 1000.01 -1300.00; Ra-ML, 1300.01 - 1600.00; RaM, 1600.01 - 1900.00; Ra-MH, 1900.01 - 2200.00; Ra-HM, 2200.01 - 2500.00; and Ra-H, 2500.01 - 3700.00) for analysis. Similar categories were created for Maximum annual temperature $\left({ }^{\circ} \mathrm{C}\right.$; Max-L, 22.51- 24.50; Max-ML, 24.51 26.50; Max-M, 26.51 -28.50; Max-MH, 28.51 -30.50; and Max-H, 30.51 - 32.50) and Minimum annual minimum temperature $\left({ }^{\circ} \mathrm{C}\right.$; Min-L, 14.51- 16.50; Min-ML, 16.51-18.50; Min-M, 18.51 - 20.5; Min-MH, 20.51 - 22.50; and Min-H, 22.51 24.50). Holdridge Life Zone shapefiles for Puerto Rico are derived from Ewel and Whitmore (1973), who used biotemperature and precipitation to classify the island's landscape into six life zones: Subtropical dry forest (df-S), Subtropical moist forest (mf-S), Subtropical wet forest (wf-S), Subtropical rain forest (rf-S), Subtropical lower montane wet forest (wf-LM), and Subtropical lower montane rain forest (rf-LM). Finally, simplified land cover shapefiles for the island $(15 \mathrm{~m}$ resolution resampled to $5 \mathrm{~m}$; Gould et al. 2008) group the island's cover into eight different classes: Water, Forested wetlands, Non-forested wetlands, Natural barren, Urban, Non-woody vegetation, Woodland and shrubland, and Forest. The DragonflyData polygon was combined with these ecological and bioclimatic layers by using ArcGIS Spatial Join Tool under Analysis Tools. Raster datasets for Annual precipitation, Maximum annual temperature and Minimum annual 
temperature were converted to polygon with the Raster to Polygon tool under Conversion Tools prior to joining. Attribute tables for the joined layers were exported to MS Excel for further analysis.

We examined the distribution of odonates across different categories for each ecological data set by means of Chi-square goodness of fit tests $(\propto=0.05)$ using Minitab (Version 18, Minitab Statistical Software, Inc.). Tests were conducted for the number of individuals, number of genera, and number of species., as well as the distribution of the most common species. Expected frequencies for the goodness of fit analysis were determined based on the proportion of the area of the island that each category represents. The relationship between species and area, and the prediction that the number of species will increase as the area being studied increases, is a fundamental tenet of ecology even though some aspects remain contentious (Lomolino 2000, Tjorve et al. 2008). We analyzed species diversity across categories for each dataset by estimating Shannon-Wiener diversity indexes using PAST (PAST 3.0, Hammer et al. 2001). We used $t$-tests were to compare diversity indexes using $\propto=0.05$ adjusted by means of Bonferroni corrections.

\section{Results}

A total of 1,754 specimens representing 19 genera and 30 species were collected, which represents $61.2 \%$ of the species reported for the island by Paulson (2004). Figure 2 shows the abundance of the species collected, from common to rare. Enallagma coecum (Hagen) (Figure 3), Erythrodyplax umbrata (Linnaeus) (Figure 4), Ischnura ramburii (Selys) (Figure 5), and Telebasis dominicana (Selys) were the most common species with 516 (29.42\%), 337 (19.21\%), 259 (14.93\%), and 114 $(6.49 \%)$ individuals, respectively. These numerically dominant species account for $69.78 \%$ of all the odonates sampled during the period. Nine species were very rare, with three specimens of each Brachymesia furcata (Hagen), Enallagma civile (Hagen), and Micrathyria didyma (Selys in Sagra), two specimens of each Micrathyria dissocians (Calvert), Tramea onusta (Hagen), and Triacanthagyna trifida (Rambur), and only one specimen for Tholymis citrina (Hagen), Tramea calverti (Muttkowski), and Triacanthagyna septima (Selys in Sagra). No members of the Lestidae were collected.

The individual-based cumulative species function (Figure 6) shows the curve becoming asymptotic at around 27 species, indicating that the collection effort was adequate to properly sample the species present in the area studied. No further testing on the model was conducted. Thirty-three (33) data points were excluded from the GIS analysis because incorrect coordinates were recorded. Additionally, ninety-four (94) data points were excluded from the analysis of cover type because they could not be properly classified under the cover categories considered. 

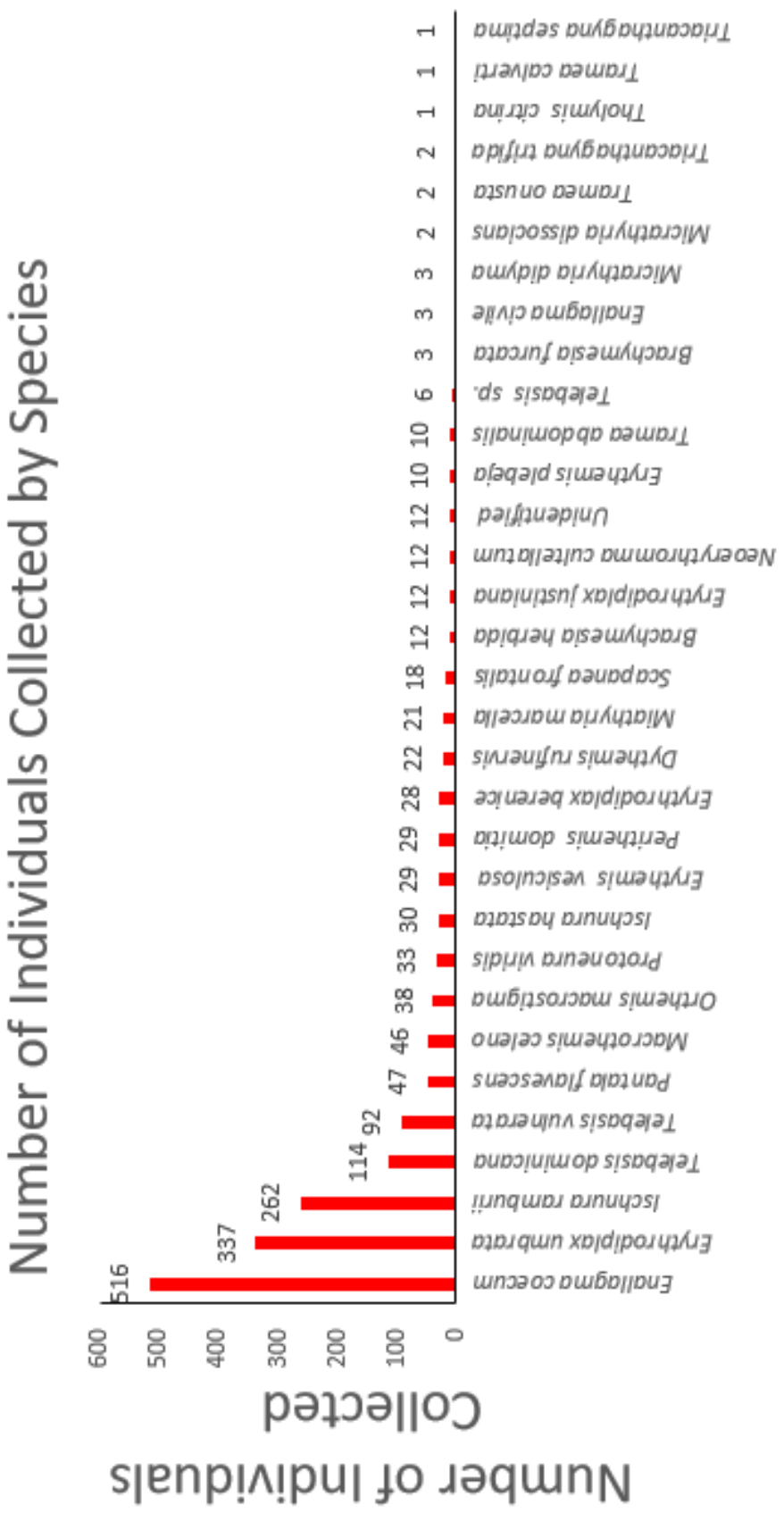


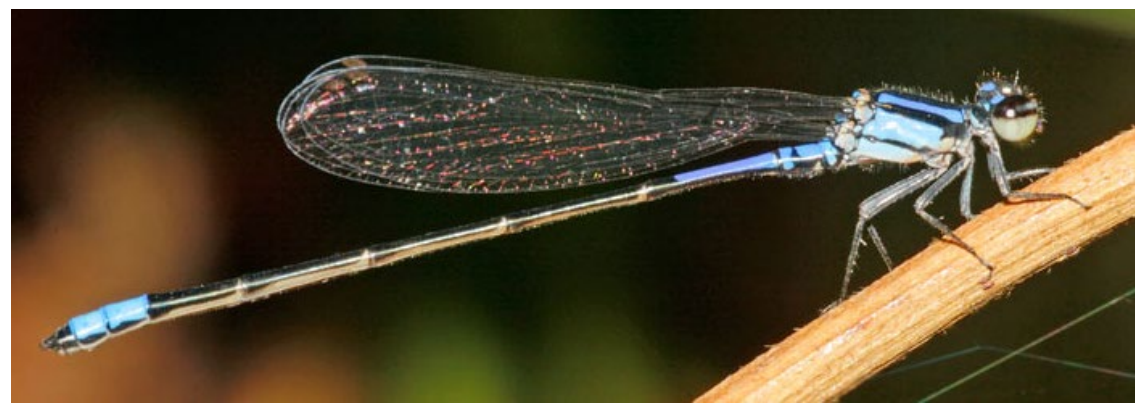

Figure 3. Enallagma coecum, male. Photo taken by Alfredo Colón Archilla (2007) at the Botanical Garden of the University of Puerto Rico, San Juan, Puerto Rico. Enallagma coecum was the most abundant species of odonatan found in this study, with 516 out of $1754(29.42 \%)$ specimens collected.

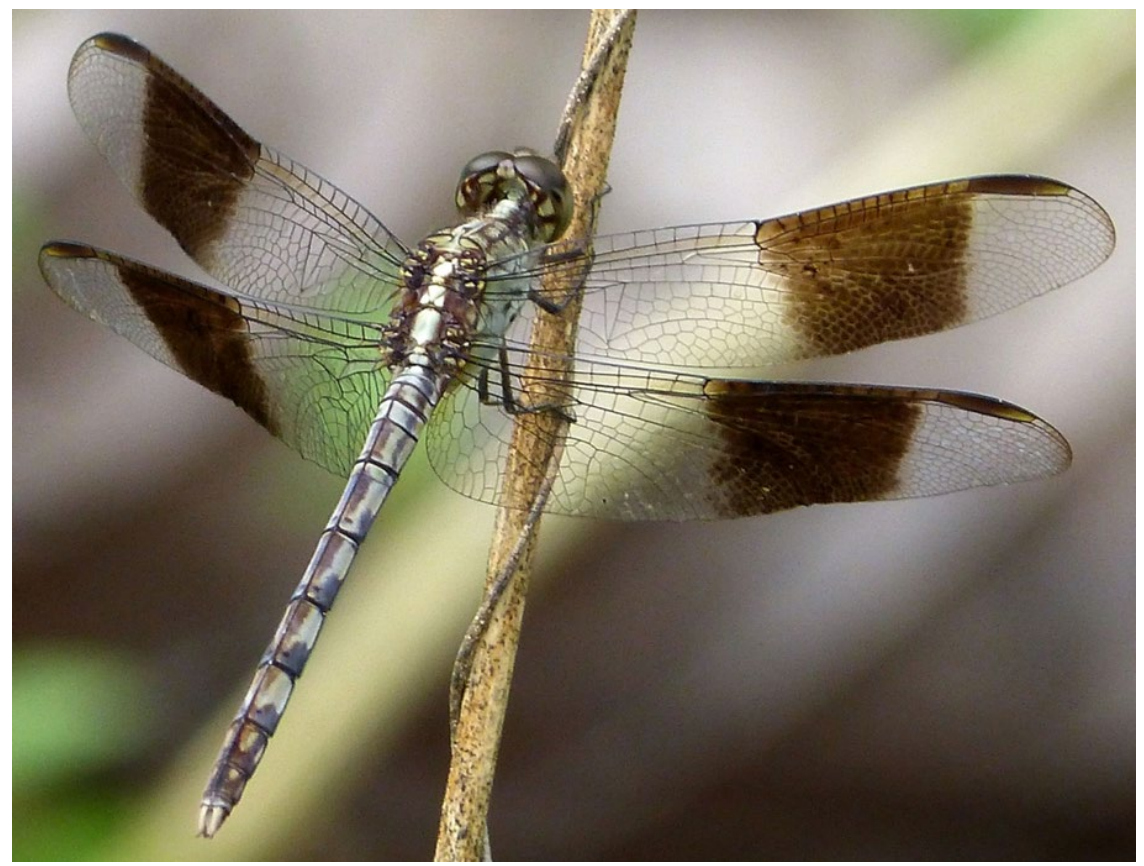

Figure 4. Erythrodiplax umbrata, male, from La Belén, Sierra de Najara, Cuba. Erythrodiplax umbrata was the second-most abundant species of odonatan found in this study, with 337 out of 1754 (19.21\%) specimens collected.

https://upload.wikimedia.org/wikipedia/commons/6/67/Male Band-winged DragonletErythrodiplax umbrata young male - Flickr - gailhampshire.jpg - gailhampshire from Cradley, Malvern, U.K [CC BY 2.0 (https://creativecommons.org/licenses/by/2.0)] 


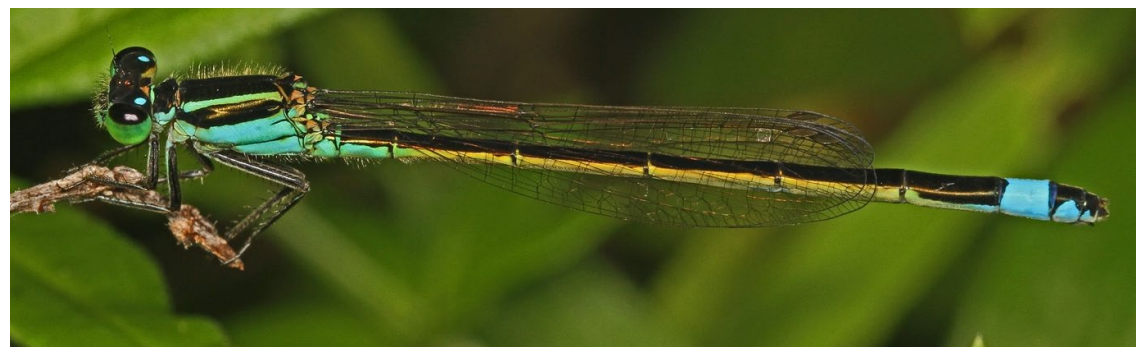

Figure 5. Ischnura ramburii, male, from Leesylvania State Park, Woodbridge, Virginia. Ischnura ramburii was the third most abundant species of odonatan found in this study, with 262 out of 1754 (14.93\%) specimens collected. https://upload.wikimedia.org/wikipedia/commons/b/b0/Rambur\% $27 \mathrm{~s}$ _Forktail __Ischnura ramburii $\% 2 \mathrm{C}$ Leesylvania_State Park $\% 2 \mathrm{C}$ _Woodbridge $\% 2 \mathrm{C}$ Virginia 8992601216.jpg . Judy Gallagher [CC BY 2.0 (https://creativecommons.org/licenses/by/2.0)]

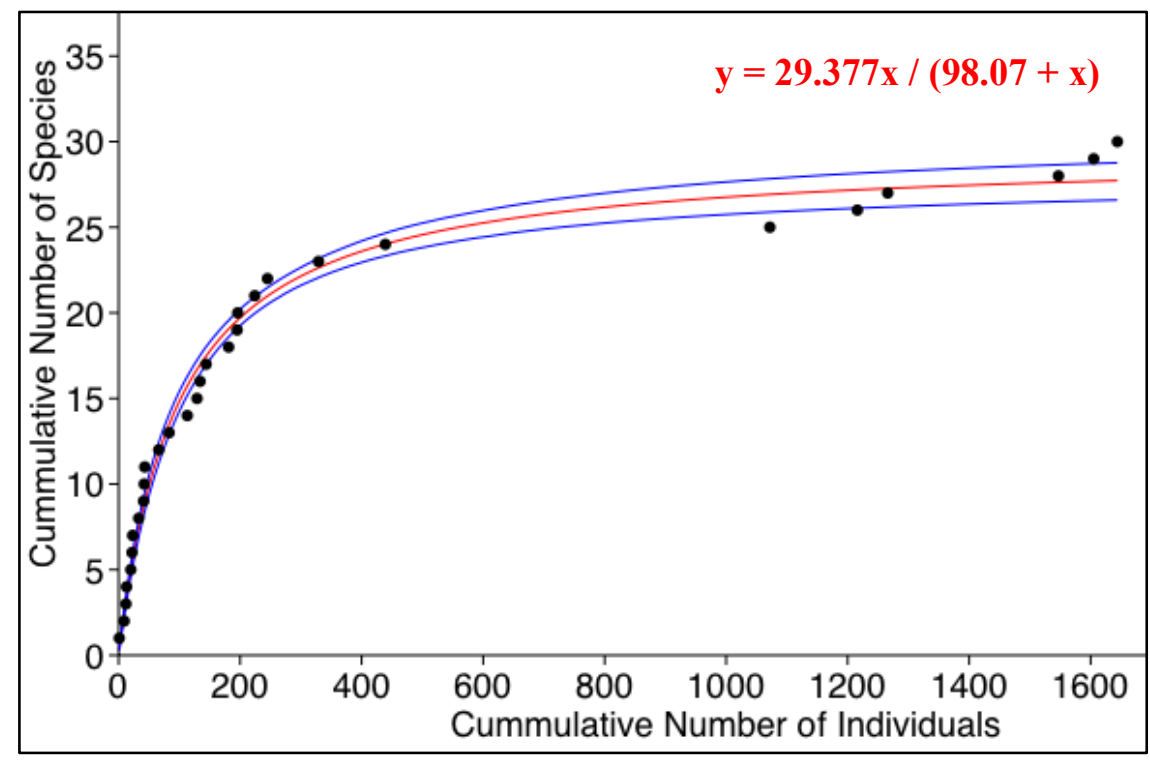

Figure 6. Individual-based species accumulation curve and 95\% confidence interval using the Michaelis-Menten equation.

Precipitation. Figure 7 shows the distribution of collection sites in relation to annual precipitation, and the number of individuals, number of genera, and number of species across annual precipitation categories are presented in Table 1. Goodness of fit tests show that there are significant differences in the number of individuals across categories $($ Chi-Square $=276.192$, d.f. $=6, p<0.05)$. By regions of precipitation, more individuals were collected in the Ra-ML (581 individuals), Ra-M (563 individuals), and 
Ra-MH (207 individuals) categories than on any of the other. However, the number of individuals was higher than expected in Ra-ML (581 observed vs. 353 expected) and lower than expected in Ra-MH (207 observed vs. 384 expected). The number of genera also differed across categories of precipitation (Chi-Square $=16.913$, d.f. $=6, p=0.01$ ), with a higher number in Ra-M (19 genera), Ra-ML (17 genera) and Ra-L (16 genera) categories. Observed values were higher than expected in Ra-L (16 observed vs. 8 expected) and lower than expected in Ra-M (19 observed vs. 57 expected). Similarly, the number of species differed across rainfall categories (Chi-Square $=23.408$, d.f. $=6$, $\mathrm{p}=0.001)$. The number of species was highest in Ra-ML (25 species), Ra-M (24 species), Ra-L (22 species), and Ra-MH (18 species) categories. Observed values were higher for the Ra-L (22 observed vs. 11 expected) category and lower for Ra-M (24 observed vs. 36 expected) and Ra-MH (18 observed vs. 27 expected) categories. Goodness of fit tests show that the distribution of the most abundant species E. coecum $($ Chi-Square $=108.947$, d.f. $=6, \mathrm{p}=0.000)$, E. umbrata $($ Chi-Square $=80.101$, d.f. $=6$, $\mathrm{p}=0.000)$ and I. ramburii $($ Chi-Square $=83.078$, d.f. $=6, \mathrm{p}=0.000)$ also differed across categories. Finally, Shannon's diversity indexes ranged from a high of 2.587 (Ra-L) to a low of $0.693(\mathrm{Ra}-\mathrm{H})$. Shannon's index for the Ra-L $\left(\mathrm{H}^{\prime}=2.587\right)$ was significantly different from those for Ra-ML $\left(\mathrm{H}^{\prime}=2.257, t=3.740, \mathrm{p}<<0.01\right)$ and $\mathrm{Ra}-\mathrm{M}\left(\mathrm{H}^{\prime}=2.182\right.$, $t=4.649, \mathrm{p}<<0.01)$ categories.

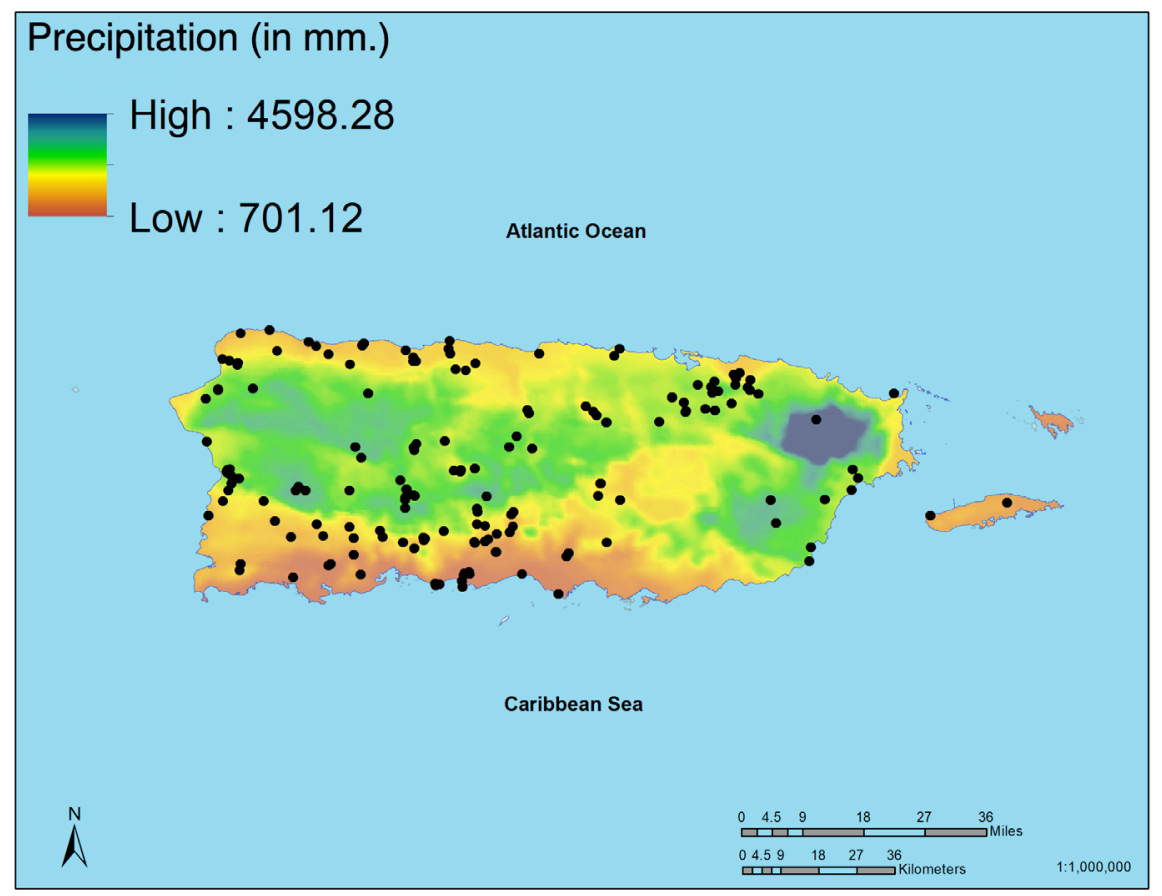

Figure 7. Distribution of collection sites across annual precipitation (in $\mathrm{mm}$ ) categories in Puerto Rico. Each dot may represent more than one individual. 
Table 1. Number of individuals, number of genera, number of species, and diversity indices across seven rainfall categories (in $\mathrm{mm}$ ) in Puerto Rico. Rainfall (Ra) categories are: Low (L), Low to Medium (LM), Medium to Low (ML), Medium (M), Medium to High (MH), High to Medium (HM) and High (H).

\begin{tabular}{|c|c|c|c|c|c|c|c|c|}
\hline \multirow[b]{2}{*}{ Species } & \multicolumn{8}{|c|}{ Rainfall } \\
\hline & $\begin{array}{c}\text { Ra-L } \\
700.01- \\
1000.00\end{array}$ & $\begin{array}{c}\text { Ra-LM } \\
1000.01- \\
1300.00\end{array}$ & $\begin{array}{c}\text { Ra-ML } \\
1300.01- \\
1600.00\end{array}$ & $\begin{array}{c}\text { Ra-M } \\
1600.01- \\
1900.00\end{array}$ & $\begin{array}{c}\text { Ra-MH } \\
1900.01- \\
2200.00\end{array}$ & $\begin{array}{c}\text { Ra-HM } \\
2200.01- \\
2500.00\end{array}$ & $\begin{array}{c}\text { Ra-H } \\
\mathbf{2 5 0 0 . 0 1 -} \\
\mathbf{3 7 0 0 . 0 0}\end{array}$ & Total \\
\hline \multicolumn{9}{|l|}{$\begin{array}{l}\text { Anisoptera - } \\
\text { Aeshnidae }\end{array}$} \\
\hline Triacanthagyna septima & 0 & 0 & 0 & 1 & 0 & 0 & 0 & 1 \\
\hline Triacanthagyna trifida & 0 & 0 & 0 & 0 & 2 & 0 & 0 & 2 \\
\hline \multicolumn{9}{|l|}{$\begin{array}{l}\text { Anisoptera - } \\
\text { Libellulidae }\end{array}$} \\
\hline Brachymesia furcata & 0 & 0 & 2 & 0 & 1 & 0 & 0 & 3 \\
\hline Brachymesia herbida & 1 & 0 & 7 & 3 & 0 & 0 & 0 & 11 \\
\hline Dythemis rufinervis & 2 & 2 & 5 & 6 & 5 & 1 & 0 & 21 \\
\hline Erythemis plebeja & 5 & 0 & 1 & 3 & 1 & 0 & 0 & 10 \\
\hline Erythemis vesiculosa & 7 & 1 & 5 & 15 & 0 & 1 & 0 & 29 \\
\hline Erythrodiplax berenice & 17 & 3 & 2 & 2 & 0 & 0 & 0 & 24 \\
\hline Erythrodiplax justiniana & 0 & 2 & 3 & 4 & 2 & 1 & 0 & 12 \\
\hline Erythrodiplax umbrata & 19 & 47 & 96 & 121 & 17 & 34 & 0 & 334 \\
\hline Macrothemis celeno & 6 & 0 & 10 & 17 & 9 & 4 & 0 & 46 \\
\hline Miathyria marcella & 4 & 1 & 11 & 3 & 2 & 0 & 0 & 21 \\
\hline Micrathyria didyma & 1 & 0 & 0 & 1 & 0 & 0 & 0 & 2 \\
\hline Micrathyria dissocians & 0 & 0 & 1 & 0 & 1 & 0 & 0 & 2 \\
\hline Orthemis macrostigma & 8 & 5 & 13 & 9 & 1 & 1 & 0 & 37 \\
\hline Pantala flavescens & 15 & 2 & 18 & 3 & 0 & 3 & 0 & 41 \\
\hline Perithemis domithia & 6 & 0 & 9 & 7 & 6 & 1 & 0 & 29 \\
\hline Scapanea frontalis & 0 & 0 & 5 & 7 & 0 & 5 & 1 & 18 \\
\hline Tholimys citrina & 0 & 0 & 0 & 1 & 0 & 0 & 0 & 1 \\
\hline Tramea abdominalis & 4 & 1 & 2 & 3 & 0 & 0 & 0 & 10 \\
\hline Tramea calverti & 1 & 0 & 0 & 0 & 0 & 0 & 0 & 1 \\
\hline Tramea onusta & 0 & 1 & 1 & 0 & 0 & 0 & 0 & 2 \\
\hline
\end{tabular}




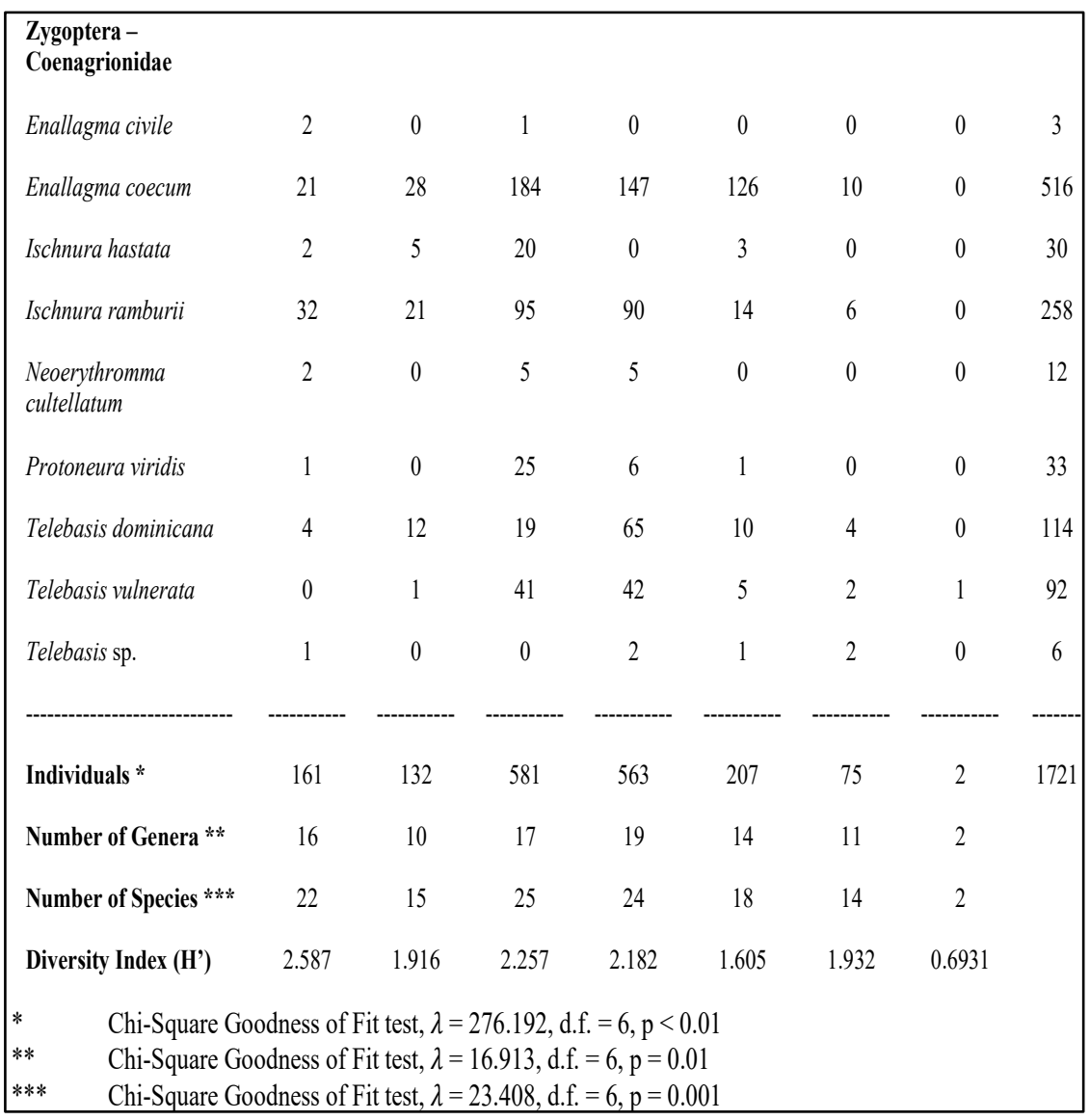

Maximum annual temperature. The distribution of individuals across maximum annual temperature categories is shown in Figure 8, and the number of individuals, number of genera, and number of species collected across these categories are presented in Table 2 . The number of individuals differed across maximum annual temperature categories $($ Chi-Square $=184.524$, d.f. $=3, p=$ 0.000 ) with more individuals collected in Max-MH (714 individuals), Max-H (698 individuals), and Max-M (290 individuals) categories than on the two remaining ones. Captures were higher than expected in Max-H (698 observed vs. 504 expected) and lower than expected in Max-MH (714 observed vs. 816 expected). The number of genera also differed across maximum annual temperature categories (Chi-Square $=10.054$, d.f. $=4, p=0.040$ ) with more genera present in Max-MH (18 genera) and Max-H (18 genera) categories than on the remaining categories. Captures were lower than expected (18 observed vs. 24 expected) in Max-MH and higher than expected (18 observed vs. 15 expected) 
in Max-H. The number of species also differed across maximum temperatures (Chi-Square $=21.531$, d.f. $=4, \mathrm{p}=0.000)$ with the highest number of species in Max-H (30 species), Max-MH (26 species), and Max-M (12 species). The number of species observed was higher than expected for Max-H (30 observed vs. 22 expected) and lower than expected for Max-MH (26 observed vs. 36 expected) category. Goodness of fit tests show that the distribution of the most abundant species $E$. coecum (Chi-Square $=111.352$, d.f. $=4, \mathrm{p}=0.000), E$. umbrata (Chi-Square $=115.172$, d.f. $=4, \mathrm{p}=0.000$ ) and I. ramburii (Chi-Square $=66.987$, d.f. $=4, p=0.000)$ also differed across maximum rainfall categories. Shannon's diversity indexes ranged from a high of $2.420(\mathrm{Max}-\mathrm{H})$ to a low of 0.377 (Max-ML). Shannon's index for Max-H was different from that of Max$\mathrm{MH}$ (H' 2.420 vs. $2.208, t=-3.287, \mathrm{p}<<0.01$ ). Similarly, the index for Max-MH differed from that of Max-M (H' 2.208 vs. 1.576, $t=-7.605, \mathrm{p}<<0.01$ ).

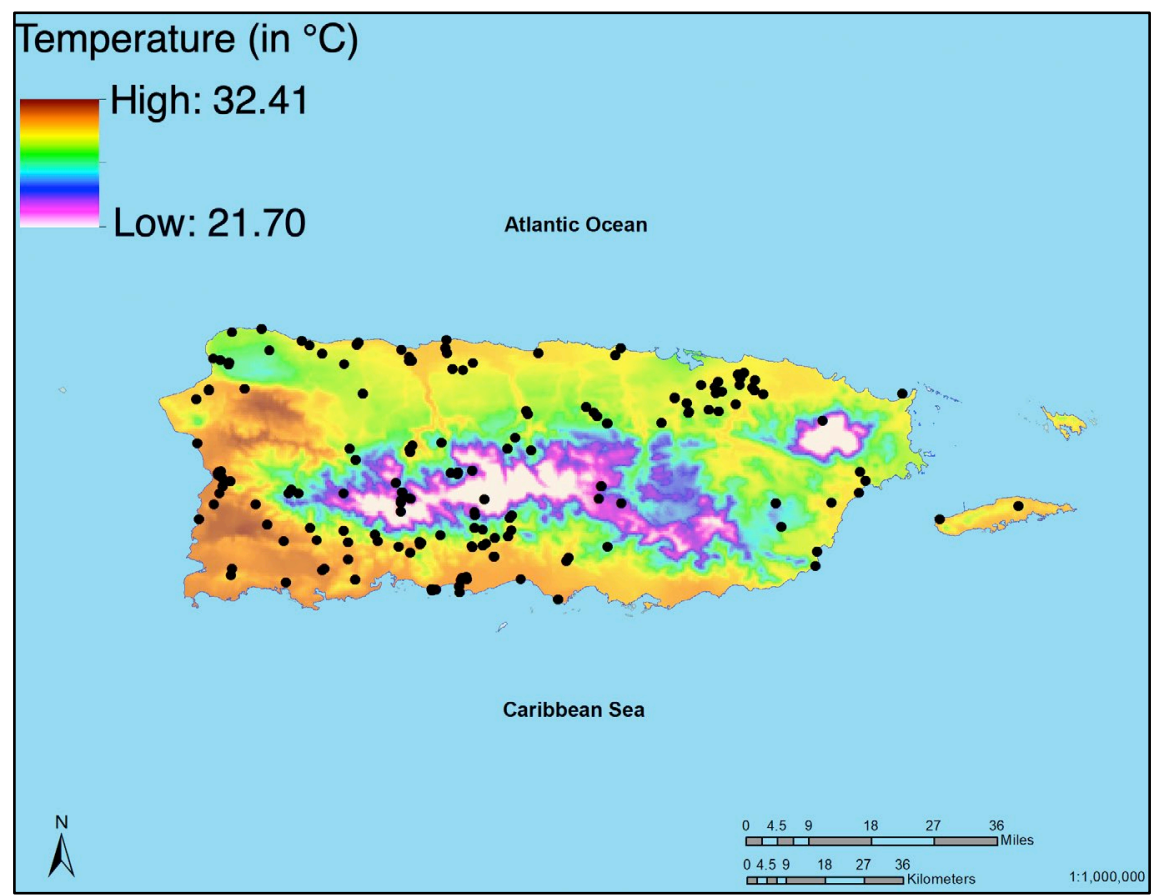

Figure 8. Distribution of collection sites across maximum annual temperature (in ${ }^{\circ} \mathrm{C}$ ) categories in Puerto Rico. Each dot may represent more than one individual. 
Table 2. Number of individuals, number of genera, number of species, and diversity indices across five maximum annual temperature categories (in ${ }^{\circ} \mathrm{C}$ ) in Puerto Rico. Annual maximum temperature (Max) categories are: Low (L), Medium to Low (ML), Medium (M), Medium to High (MH), and High (H).

\begin{tabular}{|c|c|c|c|c|c|c|}
\hline \multirow[b]{2}{*}{ Species } & \multicolumn{6}{|c|}{ Maximum Annual Temperature } \\
\hline & $\begin{array}{c}\text { Max-L } \\
22.51 \text { to } \\
24.50\end{array}$ & $\begin{array}{c}\text { Max-ML } \\
24.51 \text { to } \\
26.50 \\
\end{array}$ & $\begin{array}{c}\text { Max-M } \\
26.51 \text { to } \\
28.50\end{array}$ & $\begin{array}{c}\text { Max-MH } \\
28.51 \text { to } \\
30.50 \\
\end{array}$ & $\begin{array}{c}\text { Max-H } \\
\text { 30.51 to } \\
32.50 \\
\end{array}$ & Total \\
\hline \multicolumn{7}{|l|}{ Anisoptera - Aeshnidae } \\
\hline Triacanthagyna septima & 0 & 0 & 0 & 0 & 1 & 1 \\
\hline Triacanthagyna trifida & 0 & 0 & 0 & 0 & 2 & 2 \\
\hline \multicolumn{7}{|l|}{ Anisoptera - Libellulidae } \\
\hline Brachymesia furcata & 0 & 0 & 0 & 2 & 1 & 3 \\
\hline Brachymesia herbida & 0 & 0 & 0 & 5 & 6 & 11 \\
\hline Dythemis rufinervis & 0 & 0 & 4 & 7 & 10 & 21 \\
\hline Erythemis plebeja & 0 & 0 & 0 & 4 & 6 & 10 \\
\hline Erythemis vesiculosa & 0 & 0 & 1 & 10 & 18 & 29 \\
\hline Erythrodiplax Berenice & 0 & 0 & 0 & 4 & 20 & 24 \\
\hline Erythrodiplax justiniana & 0 & 0 & 1 & 7 & 4 & 12 \\
\hline Erythrodiplax umbrata & 0 & 1 & 35 & 115 & 183 & 334 \\
\hline Macrothemis celeno & 1 & 0 & 13 & 16 & 16 & 46 \\
\hline Miathyria marcella & 0 & 0 & 0 & 3 & 18 & 21 \\
\hline Micrathyria didyma & 0 & 0 & 0 & 1 & 1 & 2 \\
\hline Micrathyria dissocians & 0 & 0 & 0 & 0 & 2 & 2 \\
\hline Orthemis macrostigma & 0 & 0 & 0 & 20 & 17 & 37 \\
\hline Pantala flavescens & 0 & 0 & 3 & 11 & 27 & 41 \\
\hline Perithemis domithia & 0 & 0 & 0 & 18 & 11 & 29 \\
\hline Scapanea frontalis & 3 & 0 & 6 & 7 & 2 & 18 \\
\hline Tholimys citrina & 0 & 0 & 0 & 1 & 0 & 1 \\
\hline Tramea abdominalis & 0 & 0 & 0 & 2 & 8 & 10 \\
\hline Tramea calverti & 0 & 0 & 0 & 0 & 1 & 1 \\
\hline Tramea onusta & 0 & 0 & 0 & 1 & 1 & 2 \\
\hline
\end{tabular}




\begin{tabular}{|c|c|c|c|c|c|c|}
\hline \multicolumn{7}{|l|}{ Zygoptera - Coenagrionidae } \\
\hline Enallagma civile & 0 & 0 & 0 & 0 & 3 & 3 \\
\hline Enallagma соесum & 0 & 7 & 157 & 185 & 167 & 516 \\
\hline Ischnura hastata & 0 & 0 & 0 & 9 & 21 & 30 \\
\hline Ischnura ramburii & 0 & 0 & 7 & 171 & 80 & 258 \\
\hline Neoerythromma cultellatum & 0 & 0 & 0 & 2 & 10 & 12 \\
\hline Protoneura viridis & 0 & 0 & 16 & 5 & 12 & 33 \\
\hline Telebasis dominicana & 4 & 0 & 9 & 68 & 33 & 114 \\
\hline Telebasis vulnerata & 1 & 0 & 38 & 37 & 16 & 92 \\
\hline Telebasis sp. & 2 & 0 & 0 & 3 & 1 & 6 \\
\hline Individuals * & 11 & 8 & 290 & 714 & 698 & 1721 \\
\hline Number of Genera ** & 3 & 2 & 9 & 18 & 18 & \\
\hline Number of Species $* * *$ & 5 & 2 & 12 & 26 & 30 & \\
\hline Diversity Index (H') & 1.468 & 0.377 & 1.576 & 2.208 & 2.420 & \\
\hline $\begin{array}{l}* \text { Chi-Square Goodness of Fit } \\
* * \text { Chi-Square Goodness of } \mathrm{F} \\
* * * \text { Chi-Square Goodness of }\end{array}$ & $\begin{array}{l}\text { it } \lambda=18 \\
\text { est }, \lambda=1\end{array}$ & 524 , d.f. & $\begin{array}{l}4, p<0.0 \\
4, p<0.0 \\
=4, p<0\end{array}$ & & & \\
\hline
\end{tabular}

Minimum annual temperature. Figure 9 shows the distribution of individuals across the minimum annual temperature categories. The number of individuals, number of genera and number of species collected across these categories are presented in Table 3. The number of individuals differed across minimum temperatures categories $($ Chi-Square $=244.738$, d.f. $=4, p=0.000)$ with more individuals collected in Min-M (707 individuals), Min-MH (482 individuals), and Min-ML (313 individuals) than on the two remaining categories. Captures were higher than expected in Min-M (707 observed vs. 666 expected) and Min-MH (482 observed vs. 390 expected) and lower than expected in Min-ML (313 observed vs. 554 expected). The number of genera also differed across minimum temperature categories (Chi-Square $=75.217$, d.f. $=4, p=0.000)$ with more 
genera present in Min-M (18 genera), Min-MH (17 genera), and Min-ML (14 genera) than on the two remaining categories. The number of species also differed across minimum temperature categories (Chi-Square $=80.689$, d.f. $=4, p=0.000$ ) with the highest number of species in Min-M (28 species), Min-MH (25 species), and Min-ML (17 species) categories. The number of species observed was higher than expected in Min-MH (25 observed vs. 21 expected) and lower than expected in the Min-M (28 observed vs. 36 expected) categories. Goodness of fit tests show that the distribution of the most abundant species E. coecum (Chi-Square = 321.376, d.f. $=4, \mathrm{p}=0.000$ ), E. umbrata (Chi-Square $=118.181$, d.f. $=4, \mathrm{p}=$ 0.000 ), and I. ramburii (Chi-Square $=120.823$, d.f. $=4, \mathrm{p}=0.000$ ) also differed across minimum rainfall categories. Shannon's diversity indexes ranged from a high of 2.327 (Min-MH) to a low of 1.168 (Min-L). The diversity index for Min$\mathrm{MH}$ was not different from that of Min-M (H' 2.327 vs. $2.246, t=1.155, \mathrm{p}=0.24$ ) but differed from that of Min-H (H’2.237 vs. 2.017, $t=2.662, \mathrm{p}=0.008)$.

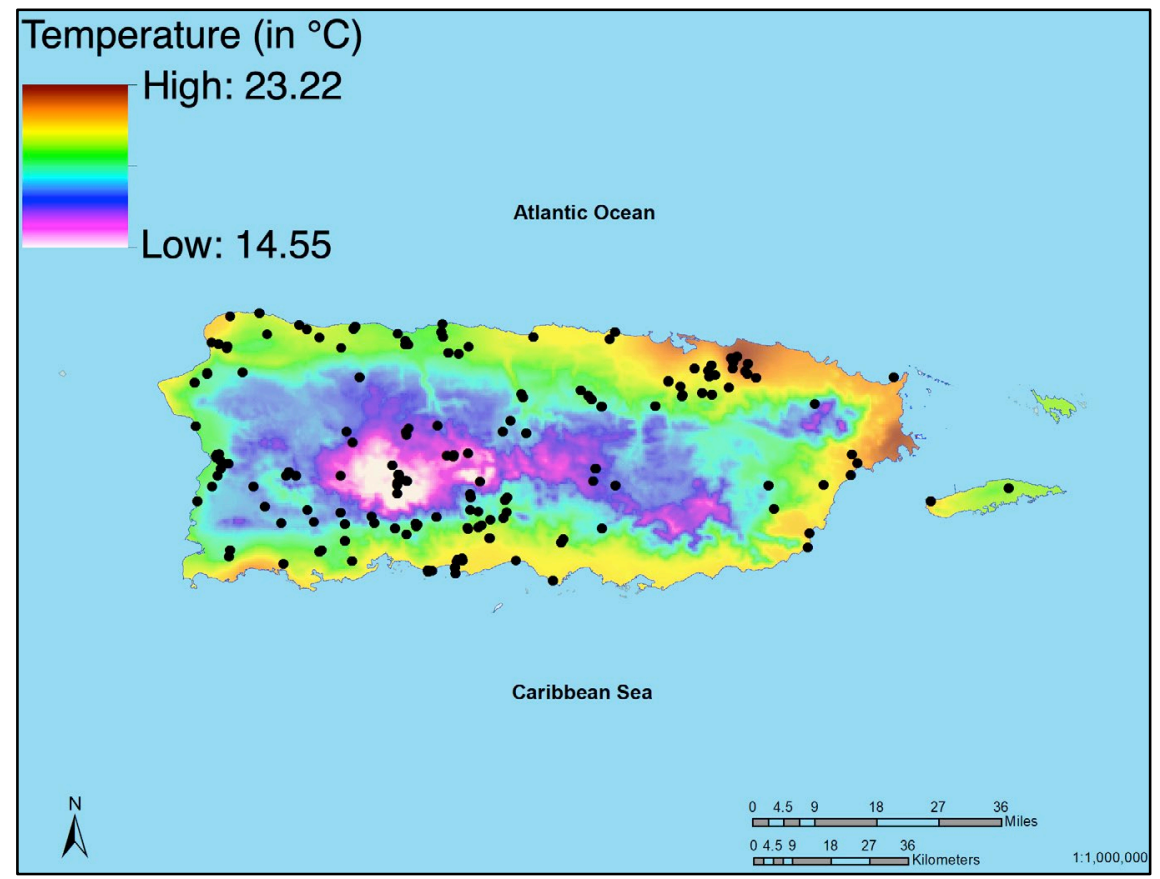

Figure 9. Distribution of collection sites across minimum annual temperature (in ${ }^{\circ} \mathrm{C}$ ) categories in Puerto Rico. Each dot may represent more than one individual. 
Table 3. Number of individuals, number of genera, number of species, and diversity indices across five minimum annual temperature categories (in ${ }^{\circ} \mathrm{C}$ ) in Puerto Rico. Annual minimum temperature (Min) categories are: Low (L), Medium to Low (ML), Medium (M), Medium to High $(\mathrm{MH})$, and High $(\mathrm{H})$.

\begin{tabular}{|c|c|c|c|c|c|c|}
\hline \multirow[b]{2}{*}{ Species } & \multicolumn{6}{|c|}{ Minimum Annual Temperature } \\
\hline & $\begin{array}{c}\text { Min-L } \\
14.51 \text { to } \\
16.50 \\
\end{array}$ & $\begin{array}{c}\text { Min-ML } \\
16.51 \text { to } \\
18.50 \\
\end{array}$ & \begin{tabular}{c|} 
Min-M \\
18.51 to \\
20.50 \\
\end{tabular} & $\begin{array}{c}\text { Min-MH } \\
20.51 \text { to } \\
22.50 \\
\end{array}$ & $\begin{array}{c}\text { Min-H } \\
22.51 \text { to } \\
24.50 \\
\end{array}$ & Total \\
\hline \multicolumn{7}{|l|}{ Anisoptera - Aeshnidae } \\
\hline Triacanthagyna septima & 0 & 0 & 1 & 0 & 0 & 1 \\
\hline Triacanthagyna trifida & 0 & 0 & 2 & 0 & 0 & 2 \\
\hline \multicolumn{7}{|l|}{ Anisoptera - Libellulidae } \\
\hline Brachymesia furcata & 0 & 1 & 2 & 0 & 0 & 3 \\
\hline Brachymesia herbida & 0 & 0 & 4 & 5 & 2 & 11 \\
\hline Dythemis rufinervis & 2 & 7 & 10 & 2 & 0 & 21 \\
\hline Erythemis plebeja & 0 & 1 & 4 & 5 & 0 & 10 \\
\hline Erythemis vesiculosa & 1 & 0 & 10 & 16 & 2 & 29 \\
\hline Erythrodiplax Berenice & 0 & 0 & 3 & 21 & 0 & 24 \\
\hline Erythrodiplax justiniana & 2 & 2 & 4 & 3 & 1 & 12 \\
\hline Erythrodiplax umbrata & 4 & 43 & 140 & 125 & 22 & 334 \\
\hline Macrothemis celeno & 12 & 10 & 13 & 10 & 1 & 46 \\
\hline Miathyria marcella & 0 & 2 & 14 & 5 & 0 & 21 \\
\hline Micrathyria didyma & 0 & 0 & 0 & 2 & 0 & 2 \\
\hline Micrathyria dissocians & 0 & 0 & 2 & 0 & 0 & 2 \\
\hline Orthemis macrostigma & 1 & 2 & 16 & 15 & 3 & 37 \\
\hline Pantala flavescens & 0 & 3 & 22 & 11 & 5 & 41 \\
\hline Perithemis domithia & 0 & 5 & 2 & 14 & 8 & 29 \\
\hline Scapanea frontalis & 6 & 5 & 7 & 0 & 0 & 18 \\
\hline Tholimys citrina & 0 & 0 & 0 & 1 & 0 & 1 \\
\hline Tramea abdominalis & 0 & 0 & 3 & 7 & 0 & 10 \\
\hline Tramea calverti & 0 & 0 & 0 & 1 & 0 & 1 \\
\hline Tramea onusta & 0 & 0 & 1 & 1 & 0 & 2 \\
\hline
\end{tabular}




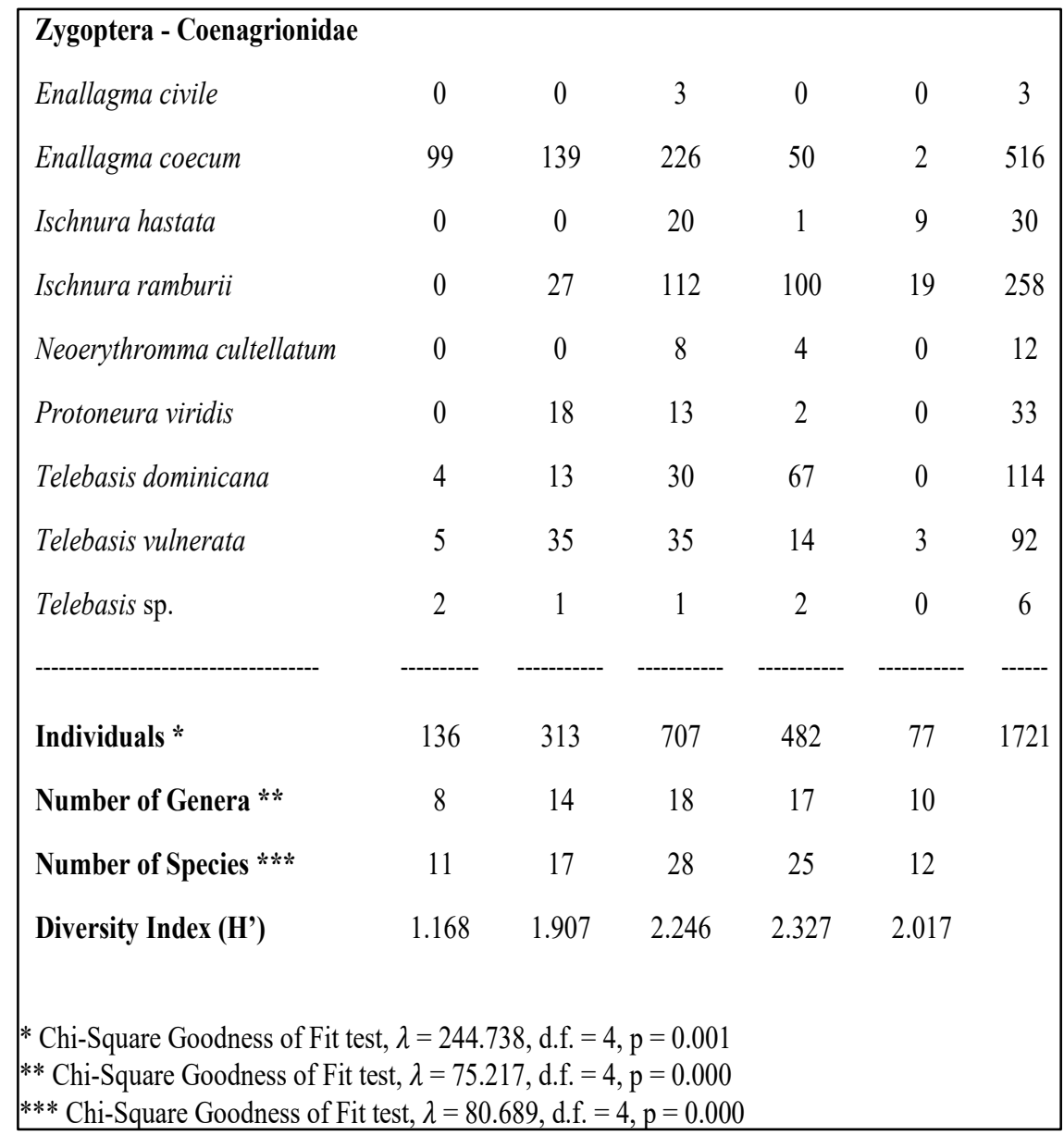

Holdridge Life Zones. The distribution of individuals across Holdridge Life Zones is shown in Figure 10, and the number of individuals, number of genera, and number of species collected across these categories are presented in Table 4. Two categories, Subtropical rain forest (rf-S) and Lower montane rain forest (rfLM) were excluded from the analysis due to lack of sampling in those areas. The number of individuals collected differed across Holdridge Life Zones (Chi-Square $=180.542$, d.f. $=3, p=0.000$ ) with the highest number of individuals collected in the mf-S life zone (1,305 individuals). Captures were higher than expected in this category (1,305 observed vs. 1,049 expected) but lower than expected in df-S (208 observed vs. 240 expected), wf-LM (11 observed vs. 21 expected), and wf-S (205 observed vs. 419 expected). The number of genera also differed across Holdridge life zones (Chi-Square $=25.846$, d.f. $=3, \mathrm{p}=0.000$ ) with more genera present in 
the mf-S (19 genera) and df-S (16 genera) life zones. The number of genera was lower than expected in mf-S (19 observed vs. 30 expected) and higher than expected in df-S (16 observed vs. 7 expected). Species richness differed across life zones (Chi-Square $=44.238$, d.f. $=3, \mathrm{p}=0.000$ ) with the highest number of species in the mf-S (29 species) and df-S (23 species). The number of species observed was higher than expected for df-S (23 observed vs. 10 expected) and lower than expected for mf-S ( 29 observed vs. 42 expected). Goodness of fit tests show that the distribution of the most abundant species $E$. coecum (Chi-Square = 51.131, d.f. $=3, \mathrm{p}=0.000)$, E. umbrata $($ Chi-Square $=125.508$, d.f. $=3, \mathrm{p}=0.000)$ and $I$. ramburii (Chi-Square $=45.307$, d.f. $=3, p=0.000$ ) also differed across maximum life zones. Shannon's diversity indexes ranged from a high of 2.627 (df-S) to a low of 1.428 (wf-S). Shannon's index for df-S was higher than that of mf-S (H' 2.627 vs. 2.219, $t=5.633, \mathrm{p}<<0.001$ ) and that of $\mathrm{mf}-\mathrm{S}$ was higher than wf-LM (H' 2.219 vs. $1.468, t=3.730, \mathrm{p}<0.01)$ and wf-S (H' 2.219 vs. $1.428, t=$ $7.955, \mathrm{p}<<0.01)$.

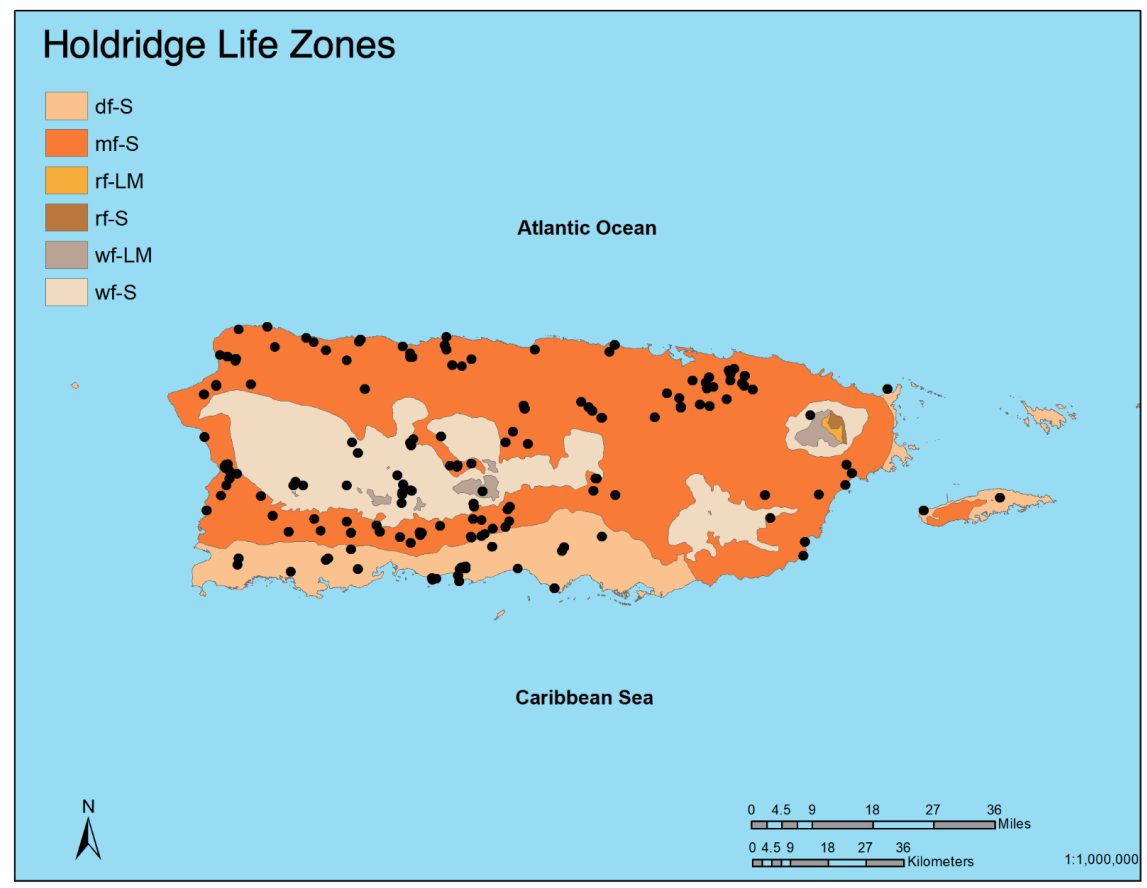

Figure 10. Distribution of collection sites across Holdridge Life Zones in Puerto Rico. Each dot may represent more than one individual. 
Table 4. Number of individuals, number of genera, number of species, and diversity indices across four Holdridge life zones in Puerto Rico. Life zones are: Subtropical dry forest (dfS), Subtropical moist forest (mf-S), Lower montane wet forest (wf-LM), and Subtropical wet forest (wf-S).

\begin{tabular}{|c|c|c|c|c|c|}
\hline \multirow[b]{2}{*}{ Species } & \multicolumn{5}{|c|}{ Holdridge Life Zones } \\
\hline & df-S & mf-S & wf-LM & wf-S & Total \\
\hline \multicolumn{6}{|l|}{ Anisoptera - Aeshnidae } \\
\hline Triacanthagyna septima & 0 & 1 & 0 & 0 & 1 \\
\hline Triacanthagyna trifida & 0 & 2 & 0 & 0 & 2 \\
\hline \multicolumn{6}{|l|}{ Anisoptera - Libellulidae } \\
\hline Brachymesia furcata & 0 & 3 & 0 & 0 & 3 \\
\hline Brachymesia herbida & 4 & 7 & 0 & 0 & 11 \\
\hline Dythemis rufinervis & 2 & 14 & 0 & 5 & 21 \\
\hline Erythemis plebeja & 5 & 5 & 0 & 0 & 10 \\
\hline Erythemis vesiculosa & 7 & 21 & 0 & 1 & 29 \\
\hline Erythrodiplax berenice & 26 & 2 & 0 & 0 & 28 \\
\hline Erythrodiplax justiniana & 0 & 9 & 0 & 3 & 12 \\
\hline Erythrodiplax umbrata & 22 & 302 & 0 & 11 & 335 \\
\hline Macrothemis celeno & 6 & 24 & 1 & 15 & 46 \\
\hline Miathyria marcella & 4 & 16 & 0 & 1 & 21 \\
\hline Micrathyria didyma & 1 & 1 & 0 & 0 & 2 \\
\hline Micrathyria dissocians & 0 & 2 & 0 & 0 & 2 \\
\hline Orthemis macrostigma & 11 & 25 & 0 & 2 & 38 \\
\hline Pantala flavescens & 19 & 23 & 0 & 0 & 42 \\
\hline Perithemis domithia & 6 & 19 & 0 & 4 & 29 \\
\hline Scapanea frontalis & 0 & 8 & 3 & 7 & 18 \\
\hline Tholimys citrina & 0 & 1 & 0 & 0 & 1 \\
\hline Tramea abdominalis & 5 & 5 & 0 & 0 & 10 \\
\hline Tramea calverti & 1 & 0 & 0 & 0 & 1 \\
\hline Tramea onusta & 2 & 0 & 0 & 0 & 2 \\
\hline
\end{tabular}




\begin{tabular}{|lccccc|}
\hline Zygoptera - Coenagrionidae & & & & & \\
Enallagma civile & 2 & 1 & 0 & 0 & 3 \\
Enallagma coecum & 21 & 366 & 0 & 129 & 516 \\
Ischnura hastata & 7 & 23 & 0 & 0 & 30 \\
Ischnura ramburii & 42 & 198 & 0 & 19 & 259 \\
Neoerythromma cultellatum & 2 & 10 & 0 & 0 & 12 \\
Protoneura viridis & 1 & 32 & 0 & 0 & 33 \\
Telebasis dominicana & 11 & 99 & 4 & 0 & 114 \\
Telebasis vulnerata & 0 & 83 & 1 & 8 & 92 \\
Telebasis sp. & 1 & 3 & 2 & 0 & 6 \\
------------------------ & ---- & ----- & -------- & ------ & ------- \\
Number of Individuals * & 208 & 1305 & 11 & 205 & 1721 \\
Number of Genera ** & 16 & 19 & 3 & 11 & \\
Number of Species *** & 23 & 29 & 5 & 12 & \\
Diversity Index (H') & 2.620 & 2.219 & 1.468 & 1.428 & \\
* Chi-Square Goodness of Fit test, $\lambda=180.542$, d.f. $=3, \mathrm{p}=0.000$ & \\
$* *$ Chi-Square Goodness of Fit test, $\lambda=25.846$, d.f. $=3, \mathrm{p}=0.000$ & \\
$* * *$ Chi-Square Goodness of Fit test, $\lambda=44.238$, d.f. $=3, \mathrm{p}=0.000$ & \\
\hline
\end{tabular}

Land cover. Figure 11 shows the distribution of individuals in relation to the island's land cover, and the number of individuals, number of genera, and number of species across annual precipitation categories are presented in Table 5. There are significant differences in the number of individuals across cover categories (Goodness of Fit Chi-Square $=41,228.700$, d.f. $=6, p=0.000$ ). More individuals were collected in Woodland and shrubland (756 individuals) and Natural barrens (366 individuals) than on any of the other cover types. However, the number of individuals was higher than expected for both of these cover types (756 observed vs. 17 expected and 366 observed vs. 16 expected, respectively). The number of genera also differed across cover types (Chi-Square $=971.515$, d.f. $=6, p=0.000$ ), with a higher number in Woodland and shrubland (18 genera), Natural barrens (17 genera), Forest (15 genera) and Built-up surfaces (11 genera) than on the other cover types. Observed values were higher than expected in the Woodland and shrubland (18 observed vs. 1 expected), Natural barrens (17 observed vs. 1 
expected), and Forest (15 observed vs. 11 expected) and lower than expected on Built-up surfaces (11 observed vs. 31 expected). The number of species also differed across cover types (Chi-Square $=1,390.290$, d.f. $=6, p=0.000$ ). Woodland and shrubland (27 species), Natural barrens (22 species), Forest (19 species), and Built-up surfaces (14 species) showed the highest species richness, while Inland water ( 5 species) had the lowest. These values were higher than expected in the Woodland and shrubland (27 observed vs. 1 expected), Natural barrens (22 observed vs. 1 expected), Forest (19 observed vs. 14 expected) and lower than expected on Built-up surfaces (14 observed vs. 42 expected). Goodness of fit tests show that the distribution of the most abundant species $E$. coecum (Chi-Square $=16,800.500$, d.f. $=6, \mathrm{p}=0.000)$, E. umbrata (Chi-Square $=7,109.890$, d.f. $=6, p=0.000)$ and . ramburii $($ Chi-Square $=4,092.770$, d.f. $=$ $6, \mathrm{p}=0.000)$ also differed across categories. Shannon's diversity indexes ranged from a high of 2.353 (Natural barrens) to a low of 1.359 (Inland water). The index for Natural barrens was higher than that of Woodland and shrubland $\left(\mathrm{H}^{\prime}=2.353\right.$ vs. $2.137, t=3.014, \mathrm{p}<0.01$ ) and of Forest cover (H'2.353 vs. 2.050, $t=3.051$, $\mathrm{p}=0.0024)$.

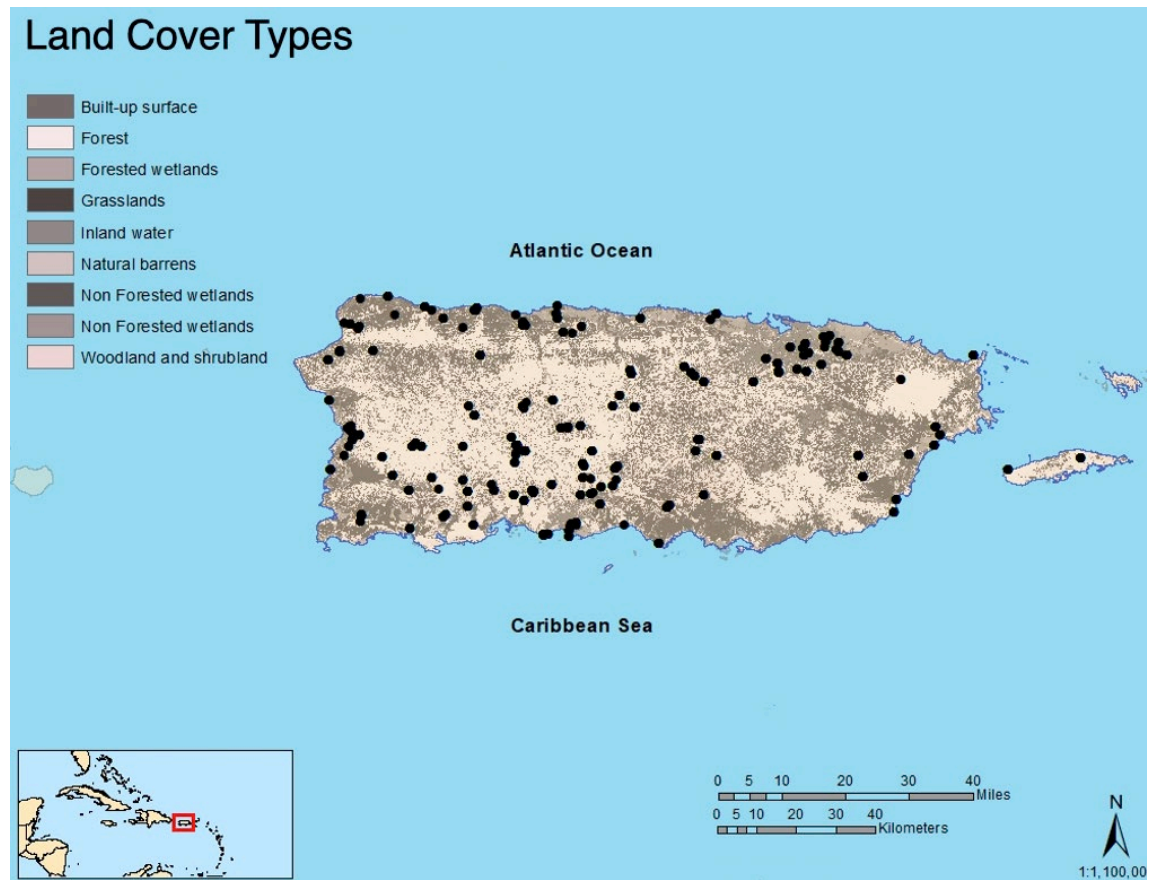

Figure 11. Map of Puerto Rico showing simplified land cover and collection sites. 
Table 5. Abundance of Odonata species across seven different types of cover in Puerto Rico.

\begin{tabular}{|c|c|c|c|c|c|c|c|c|}
\hline \multirow[b]{2}{*}{ Species } & \multicolumn{8}{|c|}{ Cover Types } \\
\hline & $\begin{array}{l}\text { Built-up } \\
\text { surface }\end{array}$ & Forest & $\begin{array}{l}\text { Forested } \\
\text { wetland }\end{array}$ & Grassland & $\begin{array}{l}\text { Inland } \\
\text { water }\end{array}$ & $\begin{array}{c}\text { Natural } \\
\text { barren }\end{array}$ & $\begin{array}{l}\text { Woodland } \\
\text { and } \\
\text { shrubland }\end{array}$ & Total \\
\hline \multicolumn{9}{|l|}{$\begin{array}{l}\text { Anisoptera - } \\
\text { Aeshnidae }\end{array}$} \\
\hline Triacanthagyna septima & 0 & 0 & 0 & 0 & 0 & 0 & 1 & 1 \\
\hline Triacanthagyna trifida & 0 & 0 & 0 & 0 & 0 & 0 & 2 & 2 \\
\hline \multicolumn{9}{|l|}{$\begin{array}{l}\text { Anisoptera - } \\
\text { Libellulidae }\end{array}$} \\
\hline Brachymesia furcata & 0 & 1 & 0 & 0 & 0 & 1 & 0 & 2 \\
\hline Brachymesia herbida & 0 & 1 & 0 & 2 & 0 & 2 & 5 & 10 \\
\hline Dythemis rufinervis & 1 & 3 & 0 & 0 & 0 & 3 & 10 & 17 \\
\hline Erythemis plebeja & 3 & 2 & 0 & 0 & 0 & 0 & 3 & 8 \\
\hline Erythemis vesiculosa & 0 & 0 & 0 & 0 & 0 & 6 & 21 & 27 \\
\hline Erythrodiplax berenice & 2 & 0 & 2 & 2 & 5 & 11 & 6 & 28 \\
\hline $\begin{array}{l}\text { Erythrodiplax } \\
\text { justiniana }\end{array}$ & 4 & 1 & 0 & 0 & 0 & 1 & 6 & 12 \\
\hline Erythrodiplax umbrata & 7 & 21 & 94 & 3 & 1 & 56 & 147 & 329 \\
\hline Macrothemis celeno & 2 & 9 & 0 & 0 & 0 & 9 & 20 & 40 \\
\hline Miathyria marcella & 2 & 2 & 0 & 0 & 0 & 5 & 8 & 17 \\
\hline Micrathyria didyma & 0 & 0 & 0 & 0 & 0 & 1 & 0 & 1 \\
\hline Micrathyria dissocians & 0 & 0 & 0 & 0 & 0 & 0 & 2 & 2 \\
\hline Orthemis macrostigma & 1 & 3 & 2 & 1 & 1 & 11 & 14 & 33 \\
\hline Pantala flavescens & 0 & 1 & 0 & 2 & 2 & 10 & 23 & 38 \\
\hline Perithemis domithia & 1 & 1 & 2 & 0 & 0 & 17 & 4 & 25 \\
\hline Scapanea frontalis & 0 & 9 & 0 & 0 & 0 & 6 & 1 & 16 \\
\hline
\end{tabular}




\begin{tabular}{|c|c|c|c|c|c|c|c|c|}
\hline Tholimys citrina & 0 & 0 & 0 & 0 & 0 & 0 & 0 & 0 \\
\hline Tramea abdominalis & 0 & 2 & 0 & 1 & 0 & 4 & 1 & 8 \\
\hline Tramea calverti & 0 & 0 & 0 & 0 & 0 & 0 & 1 & 1 \\
\hline Tramea onusta & 0 & 0 & 0 & 1 & 0 & 0 & 0 & 1 \\
\hline \multicolumn{9}{|l|}{$\begin{array}{l}\text { Zygoptera - } \\
\text { Coenagrionidae }\end{array}$} \\
\hline Enallagma civile & 0 & 0 & 0 & 0 & 0 & 0 & 1 & 1 \\
\hline Enallagma соесит & 28 & 82 & 12 & 0 & 0 & 87 & 281 & 490 \\
\hline Ischnura hastata & 0 & 0 & 5 & 0 & 0 & 0 & 24 & 29 \\
\hline Ischnura ramburii & 28 & 30 & 45 & 12 & 1 & 41 & 92 & 249 \\
\hline $\begin{array}{l}\text { Neoerythromma } \\
\text { cultellatum }\end{array}$ & 0 & 0 & 5 & 0 & 0 & 4 & 2 & 11 \\
\hline Protoneura viridis & 2 & 3 & 0 & 0 & 0 & 3 & 20 & 28 \\
\hline Telebasis dominicana & 2 & 19 & 9 & 0 & 0 & 66 & 17 & 113 \\
\hline Telebasis vulnerata & 1 & 14 & 5 & 0 & 0 & 21 & 43 & 84 \\
\hline Telebasis sp. & 0 & 2 & 0 & 0 & 0 & 1 & 1 & 4 \\
\hline & 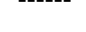 & 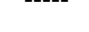 & - & . & 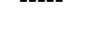 & 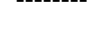 & 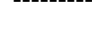 & -- \\
\hline Individuals * & 84 & 206 & 181 & 24 & 10 & 366 & 756 & 1627 \\
\hline Number of Genera ** & 11 & 15 & 7 & 6 & 4 & 17 & 18 & \\
\hline Number of Species *** & 14 & 19 & 10 & 8 & 5 & 22 & 27 & \\
\hline Diversity Index (H') & 1.859 & 2.050 & 1.462 & 1.625 & 1.359 & 2.353 & 2.137 & \\
\hline
\end{tabular}

\section{Discussion}

The odonate fauna reported for Puerto Rico is abundant and diverse, and our collection effort returned $61.2 \%$ of the total species reported by Paulson (2004). The plot of cumulative number of species against the cumulative number of individuals shows that the collection effort was adequate for the area studied. One notable observation is the absence of members of the Lestidae. The family is widespread through the Greater and Lesser Antilles (Flint et al. 2006; Meurgey 2006, 2009, 2013; Poiron and Meurgey 2011; Paulson et al. 2014), and three 
species have been reported for Puerto Rico (Klots 1932, García-Díaz 1938). Lestes forficula (Rambur) was the most common species on the island and seems to be limited to lotic habitats along the coast (García-Díaz 1938). The absence of the family points to a need for increased sampling. There was a lack of collection sites in the northwestern and southcentral parts of the island. In addition, no collections were made in areas with a combined high elevation, high annual rainfall, and mean annual maximum temperature below $26.5^{\circ} \mathrm{C}$. It is expected that an increased sampling effort will result in the addition of some of the reported species that are missing from our study.

Precipitation. Water is essential for Odonata because it affects courting (Conrad and Pritchard 1992), oviposition (Corbet 1962, Michiels and Dhondt 1990) and larval development (Corbet 1962). The results of our survey show that rainfall in Puerto Rico provides sufficient water resources to maintain a rich and diverse Odonata. Puerto Rico has an average annual rainfall of $1800 \mathrm{~mm}$. Because of orographic effects caused by the Cordillera Central there is less rainfall on the south than on the rest of the island, with quantities ranging from a maximum of 4,305 mm/yr in the Sierra de Luquillo to a minimum of $768 \mathrm{~mm} / \mathrm{yr}$ in Ensenada and Guánica (Calvesbert 1970, Ravalo et al. 1986, Gomez-Gomez et al. 2014). Rain is also unevenly distributed throughout the year, with a dry season between January and May and a rainy season from June to December. Approximately $32 \%$ of the annual rainfall becomes surface water-runoff (Carr et al. 2002). Fifty-five rivers discharge into the sea, and some water is intercepted in the 14 major dams and many smaller reservoirs and ponds throughout the island.

In Puerto Rico, Odonata are distributed across a wide range of rainfall conditions, from the wetter areas on the north and the central mountains to the drier forests on the south. Abundance, number of genera and species richness were highest in areas that experience rainfall between $1,300 \mathrm{~mm} / \mathrm{yr}$. and 1,900 $\mathrm{mm} / \mathrm{yr}$. (Ra-ML and Ra-M categories). However, the highest species diversity was observed in areas with the lowest mean annual rainfall (Ra-L, 700.01 $1000.00 \mathrm{~mm}$ ) along the southern coast of the island. This pattern is similar to that reported for Cuba, where both a higher abundance and species richness are found at lower elevations (Trapero and Naranjo 2003) which generally receive less rainfall. Reduced rainfall does not imply a lack of water resources for species living in Puerto Rico's dry areas. While streamflow in this region may be minimal (Renken et al. 1990, Kuniansky and Rodriguez 2010) sufficient resources may be available in the form of transient habitats. Temporary pools resulting from heavy rains, stormwater ponds, and man-made pools and ponds are known to be important for this insect group (Clark and Samways 1996, Pires et al. 2013, Holtman et al. 2018). For example, temporary pools and man-made structures provide habitat for the limited odonate fauna of the Marshall Islands, which lacks rivers and lakes but receives considerable rainfall (Buden 2018). Other authors have emphasized the importance of natural and man-made ponds for both aquatic 
plants and animals, including Odonata (Holtmann et al. 2018, Oertli 2018). Of particular importance are ponds associated with agricultural lands. Hofhansl and Schneeweihs (2008) showed that ponds in agricultural areas in Costa Rica had a higher Odonata species richness and supported more individuals than ponds in forest sites. Similar results have been found by Raebel et al. (2011) and Pires et al. (2013) in England and Brazil, respectively.

Loss of agricultural land and changes in irrigation practices in Puerto Rico may have driven a reduction in the water resources available for odonates, but remnants of the extensive irrigation systems may still be important. Irrigation systems on the island were being developed by the mid-1800's to satisfy the needs of the growing sugar cane industry. These early irrigation systems consisted of both underground tunnels, surface channels, and reservoirs intended to deliver surface water mostly to sugarcane fields (Kuniansky and Rodriguez 2010). Replacement of sugarcane by other crops resulted in a shift to drip irrigation and sprinkler irrigation, and the replacement of the surface water source by the use of underground water. Altogether, water use for agricultural purposes, mainly irrigation, in Puerto Rico has declined from $165 \mathrm{Mgal} / \mathrm{d}$ in 1985 (Carr et al. 1990) to $38.2 \mathrm{Mgal} / \mathrm{d}$ in 2010 (Molina-Rivera 2009, 2014). The importance of these systems in Puerto Rico was emphasized by García-Díaz (1938), who stated that "An additional habitat for the freshwater forms is the one offered by the irrigation systems developed in some parts of the Island." How important are these habitats for our local odonate fauna remains to be determined.

Temperature. Temperature is known to affect many aspects of the life history of Odonata (see review by Hassall and Thompson 2008). For example, increased temperature has been shown to affect egg development (Frances et al. 2017), larval growth rates (Pritchard et al. 2000, Suhling et al. 2015, Frances et al. 2017), larval survival (McCauley et al. 2015, 2018), and sexual coloration (Moore et al. 2018). As a consequence, the distribution of dragonflies and damselflies across the landscape may be determined by the thermal heterogeneity of the habitat and the sensitivity of the insect to temperature. Our study shows that in Puerto Rico Odonata are distributed across a wide temperature range but that overall abundance and species richness are highest in areas with a maximum annual temperature of $28.51^{\circ} \mathrm{C}$ and above (Max-MH and Max-H categories), and a minimum annual temperature between 18.51 and $22.5^{\circ} \mathrm{C}$ (Min-M and Min-MH categories). It is known that the diversity of Odonata is higher in the warmer tropics (Kalkman et al. 2008) but the role of temperature on Odonata distribution at the landscape level remains to be explored in these regions. Most of the evidence on the role of temperature on dragonfly and damselfly distribution comes from studies on the effect of habitat disturbance on odonate communities. In general, Anisoptera species richness is higher in altered habitats, which exhibit a higher air temperature, while Zygoptera species richness is higher in preserved habitats, which experience a lower but more heterogeneous temperature regime (Dolný et al. 2011; Oliveira Junior et al. 2015, 2017). We found more species of 
Anisoptera than Zygoptera at higher temperatures, however the abundance of Zygoptera was higher than that of Anisoptera in all but the highest temperature category. Our samples were dominated by two Zygoptera, the coenagrionids Enallagma coecum and Ischnura ramburii which ranked 1 st and $3 \mathrm{rd}$ in abundance in our samples, and together account for approximately $45 \%$ of the individuals collected. Enallagma coecum and I. ramburii are widespread and common in the West Indies (Poiron and Meurgey 2011, Paulson et al. 2014) and very common in Puerto Rico where the distribution of $I$. ramburii is limited to the lower elevations (García-Díaz 1938) which experience both lower rainfall and higher temperatures.

Holdridge Life Zones. Both the abundance and species richness of Odonata were higher in the Subtropical moist forest zone (mf-S) than on the other life zones. Our results also show that the highest species diversity (H') was observed in the Subtropical dry forest (df-s). These results are consistent with the precipitation data that show the highest abundance and species richness at a precipitation range between 1300 and $2200 \mathrm{~mm}$, which corresponds to the Subtropical moist forest, and the highest diversity between 700 and $1000 \mathrm{~mm}$, which corresponds to the Subtropical dry forest. These two life zones cover approximately $75 \%$ of the island (Ewel and Whitmore 1973).

While the use of the Holdridge Life Zone system is common on descriptions of study sites in Puerto Rico, we are not aware of any studies where it provides the basis for the analysis of faunal distribution in Odonata. However, a better understanding of how these insects are distributed across ecological life zones can prove to be useful for their conservation. For example, the high value for species diversity observed in the Subtropical dry forest deserves additional research. While we have already argued that significant water resources may be present on this life zone, water alone may not explain the high species diversity observed.

Land cover. Our results show that cover type is an important determinant of Odonata species assemblages in Puerto Rico. We found that both abundance and species richness were higher in the woodland and shrubland cover type, followed by natural barrens, forest, and forested wetlands. Gould et al. (2008) defined the cover types used in our study. Woodlands are defined as areas that have less than $60 \%$ tree cover and shrublands are areas with more than $25 \%$ cover by small trees and shrubs. Woodland and shrubland cover approximately 13\% of Puerto Rico's area. Natural barrens represent only $0.4 \%$ of the cover of the island and includes among other beaches, riparian flood plains, and mudflats. Forest includes areas were tree cover is greater than $60 \%$ and represent $40 \%$ of the island, while forested wetlands, which cover $1 \%$ of the island, includes both mangrove and Pterocarpus forests. Few authors have looked at the effects of land cover on Odonata distribution and abundance. Renner et al. (2018) found that among four different cover types in the Pampa biome in Brazil (grasslands, arable land, forested areas, and sand patches) forested areas had the highest relative abundance of Odonata but that species richness was higher in grasslands. While our results may appear 
to minimize the importance of forests and grasslands for Odonata, care should be exercised on making this interpretation.

Predictions about the diversity and richness of the Puerto Rican Odonata are difficult because the island's landscape has undergone significant changes over the last two centuries. Since early in the 19th century Puerto Rico experienced extensive deforestation due mostly to the need for agricultural land, and by the 1940 's the island was almost entirely deforested, with remaining forests representing only $6 \%$ of the island's land area (Birdsey and Weaver 1987). The impact of disturbance upon Odonata has been documented extensively, and the effects include a decrease in species richness, lower diversity, and a shift from more specialized to generalist species (Samways and Steytler 1995, Hofhansl and Schneeweihs 2008, Dolný et al. 2011, Brasil et al. 2014, Rodrigues et al. 2016). Because of this, Klots' and García-Díaz' publications in the 1930's may reflect an odonate fauna that was on decline due to deforestation resulting from agriculture.

An increase in industrialization and a decline in agricultural activities occurred after the 1940's, resulting in further changes to the island's landscape (Grau et al. 2003, Helmer 2004). Key among these changes are an expansion of forest and urbanized areas (Grau et al. 2003, Helmer et al. 2002, Helmer 2004), a high number of small forest patches (Lugo and Helmer 2004), and forest homogenization coupled with dominance by alien tree species (Grau et al. 2003, Lugo and Helmer 2004). As a result of this reversing trend, closed forest areas increased from $10 \%$ to approximately $42 \%$ in the 5 decades between the 1940 's to 1990's (Helmer et al. 2002). While an increase in forest cover may be perceived as having positive effects on Odonata abundance and diversity, this is not necessarily the case. For example, an increase in forest cover will result in a larger canopy cover as well as an increase in the amount of shaded areas. Remsburg et al. (2008) showed that dragonfly abundance was lower on sites with high and moderate shade on riparian habitats in South Africa. Similarly, BallDamerow et al. (2014) showed that canopy cover is negatively correlated with the abundance and richness of Odonata in temperate forests in California and Nevada, but that forest specialists increased with an increasing canopy cover. The occurrence of forest specialists is of great importance in the tropics, where forested sites generally show a high species diversity coupled with a large proportion of forest specialists (Orr 2006, Paulson 2006, Dolný et al. 2011). In our sample, only four genera (containing six species) are identified as genera with shade tolerant species by Paulson (2006), which may be an indication that some of these habitat specialists may have been eradicated from the island as a consequence of deforestation prior to the 1940's.

Recommendations. An important shortcoming of our work is the lack of sampling in zones at high altitude and with a high annual rainfall and low mean annual temperatures. While additional sites have been added after this work was 
completed, the lack of collection sites in these zones remains a drawback that needs to be addressed.

Also, we did not explore the relationship between water-body type (lotic vs. lentic) and Odonata assemblages, even though preferences for each type of habitat affect both the abundance and species diversity of the insects (Fulan and Henry 2013, Balzan 2014, Seidu et al. 2019). Similarly, variables such as water temperature, flow rate, dissolved oxygen, and riparian vegetation are known to affect Odonata (McPeek 2008, Silva, et al. 2010, Mendes et al. 2017, OliveiraJunior et al. 2017), but their study was beyond the scope of the project. Studying and understanding how Odonata interact with their environment is critical for their conservation, especially on islands such as Puerto Rico. Of particular importance is the role of anthropogenic disturbance and how it affects the insects. Because Odonata are sensitive to disturbance, they are often considered good indicators of environmental quality (Samways and Steytler 1996, Kutcher and Bried 2014, Valente-Neto et al. 2015, Pešić et al. 2017). Given the well documented patterns of land use and anthropogenic disturbance in Puerto Rico, further research on this area is encouraged. In addition, the recovery of Puerto Rico's forests presents new challenges, including those arising from increased urbanization and global climate change, both of which can be expected to have substantial impacts on the Odonata.

\section{Acknowledgements}

We thank Alonso Ramírez (Applied Ecology, North Carolina State University, Raleigh, North Carolina) for initiating and bringing the Dragonfly Project into completion. We also thank Javier Figueroa (University of Puerto Rico, Río Piedras) and the Puerto Rico - Louis Stokes Alliances for Minority Participation for providing funding for students participating on this project. Vilmaliz Rodríguez (United States Department of Agriculture, APHIS, Miami, Florida, USA) provided valuable assistance with Arc-GIS. We also thank the Biology Department at the University of Puerto Rico in Humacao for their support. The authors thank the valuable comments and suggestions made by three anonymous reviewers.

\section{Literature Cited}

Azevedo, R. R. and R. F. Krüger. 2013. The influence of temperature and humidity on abundance and richness of Calliphoridae (Diptera). Iheringia, Serie Zoologia 103(2):145-152. https://doi.org/10.1590/S0073-47212013000200010

Ball-Damerow, J. E., L. K. M'Gonigle, and V. H. Resh. 2014. Local and regional factors influencing assemblages of dragonflies and damselflies (Odonata) in California and Nevada. Journal of Insect Conservation 18(6):1027-1036. https://doi.org/10.1007/s10841-014-9709-6

Balzan, M. V. 2012. Associations of dragonflies (Odonata) to habitat variables within the Maltese Islands: a spatio-temporal approach. Journal of Insect Science 12(87):87. https://doi.org/10.1673/031.012.8701

Birdsey, R. A. and P. L. Weaver. 1987. Forest area arends in Puerto Rico. United States Department of Agriculture Forest Service. Southern Forest Experiment Station (New Orleans, Louisiana, USA). Research Note SO-331. 5 pp. https://doi.org/10.2737/SO-RN-331

Brasil, L. S., J. D. Batista, N. F. da Silva Giehl, M. B. X. Valadão, J. O. dos Santos, and K. Dias-Silva. 2014. Environmental integrity and damselfly species composition in Amazonian streams at the "arc of deforestation" region, Mato Grosso, Brazil. Acta Limnologica Brasiliensia 26(3):278287. https://doi.org/10.1590/S2179-975X2014000300007

Buden, D. W. 2018. Dragonflies and damselflies (Insecta : Odonata) of the Republic of the Marshall 
Islands. Pacific Science 72(3):1-29. https://doi.org/10.2984/72.3.8

$\mathrm{C}$ aribbean Landscape Conservation Cooperative. 2017. https://caribbeanlcc.databasin.org/maps/53f12fb5ad0844ddac2fffb07bdb8257

Carr, J. E., E. B. Chase, R. W. Paulson, and D. W. Moody. 1990. National Water Summary 1987 Hydrologic Events and Water Supply Use. United States Geological Survey. Water-Supply Paper $2350.553 \mathrm{pp}$.

Clark, T. E. and M. J. Samways. 1996. Dragonflies (Odonata) as indicators of biotope quality in the Kruger National Park, South Africa. Journal of Applied Ecology 33:1001-1012. https://doi.org/10.2307/2404681

Colwell, R. K., C. X. Mao, and J. Chang. 2004. Interpolating, extrapolating, and comparing incidencebased species accumulation curves. Ecology 85(10):2717-2727. https://doi.org/10.1890/03-0557

Conrad, K. F. and G. Pritchard. 1992. An ecological classification of odonate mating systems : the relative influence of natural, inter- and intra-sexual selection on males. Biological Journal of the Linnean Society 45:255-269. https://doi.org/10.1111/j.1095-8312.1992.tb00643.x

Corbet, P. S. 1962. A Biology of Dragonflies. Witherby. London, England, UK. 247 pp. https://medusa.jcu.edu.au/odonata digital literature/Corbet/Corbet 1962 searchable.pdf

Calvesbert, R. J. 1970. Climate of Puerto Rico and U.S. Virgin Islands. Climatography of the United States. No. 60-52. Climates of the States. United States Department of Commerce. Washington, District of Columbia, USA. 29 pp.

Daly, C., E. H. Helmer, and M. Quiñones. 2003. Mapping the climate of Puerto Rico, Vieques and Culebra. International Journal of Climatology 23(11):1359-1381. https://doi.org/10.1002/joc. 937

Dolný, A., D. Bárta, S. Lhota, and P. Drozd. 2011. Dragonflies (Odonata) in the Bornean rain forest as indicators of changes in biodiversity resulting from forest modification and destruction. Tropical Zoology 24:63-86. https://www.researchgate.net/publication/228072892_Dragonflies_Odonata_in_the_Bornean_r ain_forest_as_indicators_of_changes_in_biodiversity_resulting_from_forest_modification_and destruction

ESRI 2017. ArcGIS Desktop: Release 10.5 Environmental Systems Research Institute. Redlands, California, USA.

Ewel, J. J. and J. L. Whitmore. 1973. The Ecological Life Zones of Puerto Rico and the U.S.Virgin Islands. United States Department of Agriculture. Forest Service. Research Paper No. ITF-18, Institute of Tropical ForestryForest. Rio Piedras, Puerto Rico. 72 pp. https://www.srs.fs.usda.gov/pubs/rp/rp itf018.pdf

Flint, O. S., R. H. Bastardo, and D. E. Pérez-Gelabert. 2006. Distribution of the Odonata of the Dominican Republic. Bulletin of American Odonatology 9(3-4):67-84.

Frances, D. N., J. Y. Moon, and S. J. McCauley. 2017. Effects of environmental warming during early life history on libellulid odonates. Canadian Journal of Zoology 95(6):373-382. https://doi.org/10.1139/cjz-2016-0233

Fulan, J. Â. and R. Henry. 2013. A comparative study of Odonata (Insecta) in aquatic ecosystems with distinct characteristics. Revista Ambiência 9(3):589-604. https://doi.org/10.5935/ambiencia.2013.03.09

García-Díaz, J. 1938. An ecological survey of the fresh water insects of Puerto Rico. Part 1. The Odonata, with new life-histories. The Journal of Agriculture of the University of Puerto Rico 22(1):43-97.

Garrison, R.W., N. von Ellenrider, and J. A. Louton. 2006. Dragonfly Genera of the New World. Johns Hopkins University Press. Baltimore, Maryland, USA. 368 pp.

Garrison, R.W., N. von Ellenrider, and J.A. Louton. 2010. Damselfly Genera of the New World. Johns Hopkins University Press. Baltimore, Maryland, USA. 490 pp.

Gómez-Gómez, F., J. Rodríguez-Martínez, and M. Santiago. 2014. Hydrogeology of Puerto Rico and the Outlying Islands of Vieques, Culebra, and Mona. United States Geological Survey Investigations Map 3296, 40 p. plus 2 pls. http://dx.doi.org/10.3133/sim3296

Gotelli, N. J. and R. K. Colwell. 2001. Quantifying biodiversity: procedures and pitfalls in the measurement and comparison of species richness. Ecology Letters 4(4):379-391. https://doi.org/10.1046/j.1461-0248.2001.00230.x 
Gould, W. A., C. Alarcón, B. Fevold, M. E. Jiménez, S. Martinuzzi, G. Potts, M. Quiñones, M. Solórzano, and E. Ventosa. 2008. The Puerto Rico Gap Analysis Project. Volume I: Land Cover, Vertebrate Species Distribution, and Land Stewardship. General Technical Report IITF-GTR39. United States Departmeent of Agriculture. Forest Service. International Institute of Tropical Forestry. Río Piedras, Puerto Rico. 165 pp. https://doi.org/10.2737/IITF-GTR-39

Grau, H. R., T. M. Aide, J. K. Zimmerman, J. R. Thomlinson, E. Helmer, and X. Zou. 2003. The ecological consequences of socioeconomic and land-use changes in postagriculture Puerto Rico. BioScience 53(12):1159-1168. https://doi.org/10.1641/0006-3568(2003)053[1159:TECOSA]2.0.CO;2

Gutierrez-Fonseca, P. E., K. G. Rosas, and A. Ramírez. 2013. Aquatic insects of Puerto Rico: a list of families. Dugesiana 20(2):215-219. https://www.researchgate.net/publication/261913585 Aquatic insects of Puerto Rico a list of families

Hammer, Ø., D. A. T. Harper, and P. D. Ryan. 2001. PAST: Paleontological statistics software package for education and data analysis. Palaeontologia Electronica 4(1): 9pp. http://palaeoelectronica.org/2001_1/past/issue1_01.htm

Hassall, C. 2012. Predicting the distributions of under-recorded Odonata using species distribution models. Insect Conservation and Diversity 5(3):192-201. https://doi.org/10.1111/j.17524598.2011.00150.x

Hassall, C. and D. J. Thompson. 2008. The impacts of environmental warming on Odonata: a review. International Journal of Odonatology 11(2):131-153. https://doi.org/10.1080/13887890.2008.9748319

Helmer, E. H., O. Ramos, T. del M. López, M. Quiñones, and W. Díaz. 2002. Mapping the forest type and land cover of Puerto Rico, a component of the Caribbean diodiversity hotspot. Caribbean Journal of Science 38(3-4):165-183. https://www.fs.usda.gov/treesearch/pubs/30146

Helmer, E. H. 2004. Forest conservation and land development in Puerto Rico. Landscape Ecology 19:29-40. https://doi.org/10.1023/B:LAND.0000018364.68514.fb

Hickling, R., D. B. Roy, J. K. Hill, and C. D. Thomas. 2005. A northward shift of range in British Odonata. Global Change Biology 11:502-506. https://doi.org/10.1111/j.13652486.2005.00904.x

Hickling, R., D. B. Roy, J. K. Hill, R. Fox, and C. D. Thomas. 2006. The distributions of a wide range of taxonomic groups are expanding polewards. Global Change Biology 12(3):450-455. https://doi.org/10.1111/j.1365-2486.2006.01116.x

Hofhansl, F. P. and S. Schneeweihs. 2008. Banderillas: effects of deforestation on dragonflies (Insecta, Odonata) in the Pacific lowland of Costa Rica. pp. 237-247. In, Natural and Cultural History of the Golfo Dulce Region Costa Rica. Stapfia 88 (zugleich Kataloge der oberösterreichischen Landesmuseen Neue Serie 80) (Biologiezentrum. Oberösterreich, Oberösterreichische Landesmuseen. Linz, Austria). 768 pp.

Holtmann, L., M. Juchem, J. Brüggeshemke, A. Möhlmeyer and T. Fartmann. 2018. Stormwater ponds promote dragonfly (Odonata) species richness and density in urban areas. Ecological Engineering 118:1-11. https://doi.org/10.1016/j.ecoleng.2017.12.028

Kalkman, V. J., V. Clausnitzer, K. D. B. Dijkstra, A. G. Orr, D. R. Paulson, and J. Van Tol. 2008. Global diversity of dragonflies (Odonata) in freshwater. Hydrobiologia 595(1):351-363. https://doi.org/10.1007/s10750-007-9029-x

Klots, E. B. 1932. Insects of Porto Rico and the Virgin Islands: Odonata or dragon flies. Scientific Survey of Porto Rico and the Virgin Islands Volume 19, Part 1. 107 pp. plus 7 plates.

Kuniansky, E. L. and J. M. Rodríguez. 2010. Effects of Changes in Irrigation Practices and Aquifer Development on Groundwater Discharge to the Jobos Bay National Estuarine Research Reserve near Salinas, Puerto Rico. United States Geological Survey. Scientific Investigations Report 2010-5022. 106 pp. https://doi.org/10.3133/sir20105022

Kutcher, T. E. and J. T. Bried. 2014. Adult Odonata conservatism as an indicator of freshwater wetland condition. Ecological Indicators 38:31-39. https://doi.org/10.1016/j.ecolind.2013.10.028

Lara-Pérez, L. A., J. Campos-Domínguez, F. Díaz-Fleischer, J. Adame-García, and A. AndradeTorres. 2017. Species richness and abundance of Saturniidae (Lepidoptera) in a tropical semideciduous forest of Veracruz, Mexico and the influence of climatic variables. Revista Mexicana de Biodiversidad 88(1):173-182. https://doi.org/10.1016/j.rmb.2016.10.020

Larsen, M. C., and A. J. Torres-Sánchez. 1996. Geographic relations of landslide distribution and 
assessment of landslide hazards in the Blanco, Cibuco, and Coamo river basins, Puerto Rico. United States Geological Survey. Water-Resources Investigations Report 95-4029. San Juan, Puerto Rico. 56 pp. https://pubs.usgs.gov/wri/1995/4029/report.pdf

Liberal, C. N., Â. M. Isidro de Farias, M. V. Meiado, B. K. C. Filgueiras, and L. Iannuzzi. 2011. How habitat change and rainfall affect dung beetle diversity in Caatinga, a Brazilian semi-arid ecosystem. Journal of Insect Science 11(114):1-11. https://doi.org/10.1673/031.011.11401

Lomolino, M. V. 2000. Ecology's most general, yet protean pattern: The species-area relationship. Journal of Biogeography 27(1):17-26. https://doi.org/10.1046/j.1365-2699.2000.00377.x

Lugo, A. E. and E. Helmer. 2004. Emerging forests on abandoned land: Puerto Rico's new forests. Forest Ecology and Management 190(2-3):145-161. https://doi.org/10.1016/j.foreco.2003.09.012

McCauley, S. J., J. I. Hammond, D. N. Frances, and K. E. Mabry. 2015. Effects of experimental warming on survival, phenology and morphology of an aquatic insect (Odonata). Ecological Entomology 40(3):2011-2220. https://doi.org/10.1002/cncr.27633.

McCauley, S. J., J. I. Hammond, and K. E. Mabry. 2018. Simulated climate change increases larval mortality, alters phenology, and affects flight morphology of a dragonfly. Ecosphere 9(3): e02151. https://doi.org/10.1002/ecs2.2151

McPeek, M. 2008. Ecological factors influencing the distribution and abundances of Odonata. pp. 5162. In, Córdoba-Aguilar, A. (Editor). Dragonflies and Damselflies: Model Organisms for Ecological and Evolutionary Research. Oxford Scholarship Online. Oxford University Press, Oxford, England, UK. 304 pp. https://doi.org/10.1093/acprof:oso/9780199230693.003.0005

Mendes, T. P., A. Luiza-Andrade, H. S. R. Cabette, and L. Juen. 2017. How does Environmental variation affect the distribution of dragonfly larvae (Odonata) in the Amazon-Cerrado transition zone in Central Brazil? Neotropical Entomology 47(1):37-45. https://doi.org/10.1007/s13744017-0506-2

Meurgey, F. 2006. A contribution to the knowledge of the Odonata of Dominica (British West Indies). Contribution to Odonatology (Nantes Museum of Natural History, NMNH, Ministry of Agriculture, Nantes, France) 4:1-22.

Meurgey, F. 2009. The Odonata of Grenada (Lesser Antilles). Contribution to Odonatology (Nantes Museum of Natural History, NMNH, Ministry of Agriculture, Nantes, France) No. 1.33 pp.

Meurgey, F. 2013. A catalogue of the West Indian dragonflies (Insecta: Odonata). Annales de La Societe Entomologique de France 49(3):298-334. http://dx.doi.org/10.1080/00379271.2013.848066

Michiels, N. K. and A. A. Dhondt. 1990. Costs and benefits associated with oviposition site selection in the dragonfly Sympetrum danae (Odonata: Libellulidae). Animal Behaviour 40(4):668-678. https://doi.org/10.1016/S0003-3472(05)80696-7

Minitab. 2017. Minitab LLC. State College, Pennsylvania, USA.

Molina-Rivera, W. L. 2009. Source, Use, and Disposition of Freshwater in Puerto Rico, 2005. United States Geological Service. Fact Sheet 2009-3080. 5 pp. https://pubs.usgs.gov/fs/2009/3080/pdf/FS2009 3080.pdf

Molina-Rivera, W. L. 2014. Estimated Water Use in Puerto Rico, 2010. United States Geological Service. Open File Report 2014-1117. 35 pp. http://dx.doi.org/10.3133/ofr20141117

Moore, M. P., C. Lis, I. Gherghel, and R. A. Martin. 2018. Temperature shapes the costs, benefits and geographic diversification of sexual coloration in a dragonfly. Ecology Letters 22(3):437-446. https://doi.org/10.1111/ele. 13200

Oertli, B. 2010. The local species richness of Dragonflies in mountain waterbodies: an indicator of climate warming? BioRisk 5:243-251. https://doi.org/10.3897/biorisk.5.853

Oertli, B. 2018. Editorial: Freshwater biodiversity conservation: The role of artifical ponds in the $21 \mathrm{st}$ century. Aquatic Conservation: Marine Freshwater Ecosystem 28:264-269. https://doi.org/10.1002/aqc.2902

Oliveira-Junior, J. M. B., Y. Shimano, T. A. Gardner, R. M. Hughes, P. de Marco Júnior, and L. Juen. 2015. Neotropical dragonflies (Insecta: Odonata) as indicators of ecological condition of small streams in the eastern Amazon. Austral Ecology 40(6):733-744. https://doi.org/10.1111/aec.12242

Oliveira-Junior, J. M. B. de, P. De Marco, P., K. Dias-Silva, R. P. Leitão, C. G. Leal, P. S. Pompeu, T. A. Gardner, R. M. Hughes, and L. Juen. 2017. Effects of human disturbance and riparian conditions on Odonata (Insecta) assemblages in eastern Amazon basin streams. Limnologica 
66(1):31-39. https://doi.org/10.1016/j.limno.2017.04.007

Orr, A. G. 2006. Odonata in Bornean tropical rain forest formations : diversity, endemicity and implications for conservation management. pp. 51-78. In, A. Cordero-Rivera (Editor). Forests and Dragonflies. Fourth WDA International Symposium of Odonatology. Pensoft Publishers. Sofia (Bulgaria) - Moscow (Russia). 299 pp.

Paulson, D. R. 2001. Recent Odonata records from southern Florida - effects of global warming? International Journal of Odonatology 4(1):57-59. https://doi.org/10.1080/13887890.2001.9748159

Paulson, D. R. 2004. Critical species of Odonata in the Neotropics. International Journal of Odonatology 7(2):163-188. https://doi.org/10.1080/13887890.2004.9748208

Paulson, D. R. 2006. The importance of forests to neotropical dragonflies. pp. 79-10. In, A. CorderoRivera, A. (Editor). Forests and Dragonflies. Fourth WDA International Symposium of Odonatology. Pensoft Publishers. Sofia (Bulgaria) - Moscow (Russia). 299 pp.

Paulson, D. R., C. de Haseth, and A. O. Debrot. 2014. Odonata of Curaçao, southern Caribbean, with an update to the fauna of the ABC islands. International Journal of Odonatology 17(4):237-249. https://doi.org/10.1080/13887890.2014.981877

Peacock, L., S. Worner, and R. Sedcole. 2006. Climate variables and their role in site discrimination of invasive insect species distributions. Environmental Entomology 35(4):958-963. https://doi.org/10.1603/0046-225X-35.4.958

Pešić, V., B. Gligorović, A. Savić, and P. Buczyński. 2017. Ecological patterns of Odonata assemblages in karst springs in central Montenegro. Knowledge \& Management of Aquatic Ecosystems 418.3:1-20. https://doi.org/10.1051/kmae/2016035 ， https://www.kmaejournal.org/articles/kmae/pdf/2017/01/kmae160138.pdf

Pires, M. M., C. B. Kotzian, M. R. Spies, and D. B. Neri. 2013. Diversity of Odonata (Insecta) larvae in streams and farm ponds of a montane region in southern Brazil. Biota Neotropica 13(3):259267. https://doi.org/10.1590/S1676-06032013000300028

Poiron, C. and F. Meurgey. 2011. The Odonata of St Lucia (Lesser Antilles). L'Herminier Natural History Society. St. Lucia. Survey Report March 9-30 2011. Contribution to Odonatology No. 2. 22 pp. http://www.shnlh.org/ressources/pdf/entomologie/rapports/Odonata\%20St\%20Lucia.pdf

Powney, G. D., S. S. A. Cham, D. Smallshire, and N. J. B. Isaac. 2015. Trait correlates of distribution trends in the Odonata of Britain and Ireland. PeerJ 3:e1410. https://doi.org/10.7717/peerj.1410

Pritchard, G., L. D. Harder, A. Kortello, and R. Krishnaraj. 2000. The response of larval growth rate to temperature in three species of coenagrionid dragonflies with some comments on Lestes disjunctus (Odonata: Coenagrionidae, Lestidae). International Journal of Odonatology 3(2):105-110. https://doi.org/10.1080/13887890.2000.9748141

Raebel, E. M., T. Merckx, R. E. Feber, P. Riordan, D. W. MacDonald, and D. J. Thompson. 2011. Identifying high-quality pond habitats for Odonata in lowland England: Implications for agrienvironment schemes. Insect Conservation and Diversity 5(6):422-432. https://doi.org/10.1111/j.1752-4598.2011.00178.x

Ravalo, E. J., M. R. Goyal, and C. R. Almodóvar. 1986. Average monthly and annual rainfall distribution in Puerto Rico. Journal of Agricultue of the University of Puerto Rico 70(4):267-275.

Remsburg, A. J., A. C. Olson, and M. J. Samways. 2008. Shade alone reduces adult dragonfly (Odonata: Libellulidae) abundance. Journal of Insect Behavior 21(6):460-468. https://doi.org/10.1007/s10905-008-9138-z

Renken, R. A., P. Díaz, F. Gomez-Gomez, and V. Quiñones-Aponte. 1990. A Hydrologic Excursion to Puerto Rico's Southern Plain. US Geological Service Open File Report 90-365. Doraville, Georgia, USA. 24 pp. https://doi.org/10.3133/ofr90365

Renner, S., E. Périco, M. S. Dalzochio, and G. Sahlén. 2018. Water body type and land cover shape the dragonfly communities (Odonata) in the Pampa biome, Rio Grande do Sul, Brazil. Journal of Insect Conservation 22(1):113-125. https://doi.org/10.1007/s10841-017-0042-8

Rodrigues, M. E., F. de Oliveira Roque, J. M. Ochoa Quintero, J. C. de Castro Pena, J, D. C. de Sousa, and P. De Marco Junior. 2016. Nonlinear responses in damselfly community along a gradient of habitat loss in a savanna landscape. Biological Conservation 194:113-120. https://doi.org/10.1016/j.biocon.2015.12.001

Samways, M. J. and Steytler, N. S. 1996. Dragonfly (Odonata) distribution patterns in urban and forest 
landscapes, and recommendations for riparian management. Biological Conservation 78:279288. https://doi.org/10.1016/S0006-3207(96)00032-8

Seidu, I., C. A. Nsor, E. Danquah, P. Tehoda, and S. K. Oppong. 2019. Patterns of Odonata Assemblages in Lotic and Lentic Systems in the Ankasa Conservation Area, Ghana. International Journal of Zoology 2019:1-14. https://doi.org/10.1155/2019/3094787

Silva, D. de paiva, P. De Marco, and D. C. Resende. 2010. Adult odonate abundance and community assemblage measures as indicators of stream ecological integrity: A case study. Ecological Indicators 10(3):744-752. https://doi.org/10.1016/j.ecolind.2009.12.004

Suhling, F., I. Suhling, and O. Richter. 2015. Temperature response of growth of larval dragonflies an overview. International Journal of Odonatology 18(1):15-30. https://doi.org/10.1080/13887890.2015.1009392

Taylor, M. and E. Alfaro. 2005. Climate of Central America and the Caribbean. pp. 183-189. In, J. E. Oliver (Editor). Encyclopedia of World Climatology. Encyclopedia of Earth Sciences Series. Springer, Netherlands. https://doi.org/10.1007/1-4020-3266-8_37

Tjørve, E. and K. M. Calf Tjørve. 2008. The species-area relationship, self-similarity, and the true meaning of the z-value. Ecology 89(12):3528-3533. https://doi.org/10.1890/07-1685.1

Trapero-Quintana, A. and C. Naranjo Lopez. 2003. Revision of the Order Odonata in Cuba. Bulletin of American Odonatology 7(2):23-40. https://static1.squarespace.com/static/5bf443d3f8370a0c796d6447/t/5d73dae76d7e84225d76ce e2/1567873788307/BAO_2003_7_2.pdf

Valente-Neto, F., F. De Oliveira Roque, M. E. Rodrigues, L. Juen, and C. M. Swan. 2015. Toward a practical use of Neotropical odonates as bioindicators: Testing congruence across taxonomic resolution and life stages. Ecological Indicators 61:952-959. https://doi.org/10.1016/j.ecolind.2015.10.052

Westfall, M. J., Jr. and M. L. May. 2006. Damselflies of North America. Second Edition. Scientific Publishers. Gainesville, Florida, USA. 550pp. 